\title{
Os sete pecados capitais e os processos de culpabilização em manuais de devoção do século XVIII
}

\author{
Eliane Cristina Deckmann Fleck* \\ Mauro Dillmann ${ }^{*}$
}

\section{RESUMO}

Neste artigo, analisamos o manual de devoção Mestre da vida que ensina a viver e morrer santamente, escrito pelo dominicano português João Franco, em 1731, a partir das representaçôes dos pecados capitais que apresenta, das recomendaçóes que faz para combatê-los e dos "remédios" que propôe para a salvação das almas. A análise considera, ainda, as estratégias discursivas empregadas pelo célebre pregador para promover a interiorização da culpa e o arrependimento nos leitores católicos. Com o intuito de evidenciar a circulaçáo e a difusáo de percepções sobre pecado e culpa e, sobretudo, sobre a salvação das almas na primeira metade do século XVIII, as orientaçôes divulgadas no Mestre da vida são cotejadas com as imagens sobre as penas que os pecadores sofreriam no inferno, que ilustram a obra Desengano dos pecadores, escrita em 1724, pelo padre jesuíta Alexandre Perier.

Palavras-chave: pecados capitais; salvação; inferno; culpa; manuais de devoção.

\section{ABSTRACT}

In this article, we analyze the devotion manual Mestre da vida que ensina a viver e morrer santamente, (Master of Life that Teaches How to Saintly Live and Die), written in 1731 by the Portuguese Dominican João Franco. The analysis focus on the representations of the deadly sins, the advice to combat them, and the "remedies" suggested for the salvation of souls. It also approaches the discursive strategies employed by the celebrated preacher to promote repentance and internalization of guilt in Catholic readers. To highlight the circulation and diffusion of perceptions of sin and guilt and, above all, on the salvation of souls in the first half of the eighteenth century, the guidance offered in Mestre da vida is compared to images of the punishment suffered by sinners in Hell, which illustrate the work Desengano dos pecadores (Sinners Disillusion), written in 1724 by Jesuit priest Alexandre Perier.

Keywords: deadly sins; salvation; Hell; guilt; devotion manuals. 
E que contaremos então aos pecadores se não podemos ameaçá-los com um inferno imediato, logo após a morte?! Umberto Eco, O nome da rosa

\section{Introdução}

A literatura religiosa foi extremamente profícua na Península Ibérica durante o século XVIII. Sermôes, catecismos, missais e manuais de devoção, que já vinham sendo redigidos desde a Baixa Idade Média, tiveram — acompanhando o significativo incremento das práticas de leitura - expressivo crescimento editorial e promoveram novas formas de sociabilidade familiar e pública. ${ }^{1}$ Compradas, lidas e utilizadas tanto por leigos quanto por religiosos, tais obras circularam também no Brasil, ${ }^{2}$ integrando o acervo de bibliotecas religiosas, como a da chamada Livraria da Fazenda jesuítica de Santa Cruz, no Rio de Janeiro. ${ }^{3}$ Entre as obras dessa literatura doutrinal e teológica, editada e impressa com sucesso em Portugal e na Espanha, ${ }^{4}$ e divulgada no Brasil para a instruçáo religiosa dos católicos, destaca-se o manual

\footnotetext{
${ }^{1}$ JULIA, Dominique. Leituras e Contra-Reforma. In: CHARTIER, Roger; CAVALLO, Guglielmo. História da leitura no mundo ocidental. São Paulo: Ática, 1999. p. 79-116, p. 66; CHARTIER, Roger. A ordem dos livros. Brasília: Ed. UnB, 1994. p. 98.

${ }^{2}$ A historiadora Lúcia Bastos das Neves destacou que o comércio de livros no Brasil era bastante promissor, sendo "os livros de religiáo os que mais se vendiam". Entre o final do século XVIII e início do XIX, muitos livreiros franceses atuavam em Portugal e atendiam aos interesses de particulares e negociantes no Brasil que, por encomenda, requeriam livros. A autora examinou documentação "pertinente ao assunto" como "as licenças concedidas pela Mesa do Desembargo do Paço no Rio de Janeiro aos requerimentos feitos pelos livreiros para desembaraçar seus livros nas Alfândegas, os pareceres emitidos pelos censores régios, os pedidos de diversos livreiros radicados em Lisboa para despachar livros para as principais cidades do Brasil, constante da documentação da (...) Real Mesa Censória, em Portugal”. O português João Roberto Bourgeois desembarcou no Rio de Janeiro em 1782 e tornou-se um dos maiores editores no início do século seguinte, noticiando nos jornais da cidade as "obras novas" presentes na sua loja. Manteve ligaçôes, "entre 1809 e 1811, com praças de Lisboa, Porto, Luanda e Londres; e, no Brasil, com São Paulo, Santos e Porto Alegre”. NEVES, Lúcia Maria Bastos das. João Roberto Bourgeois e Paulo Martin: livreiros franceses no Rio de Janeiro, no início do oitocentos. In: ENCONTRO REGIONAL DE HISTÓRIA - ANPUH-RJ, HISTÓRIA E BIOGRAFIAS, X, 2002, Rio de Janeiro. Anais Eletrônicos do X Encontro Regional de História - História e biografias. Rio de Janeiro: Uerj, 2002. p. 3.

${ }^{3}$ RIBEIRO, Marília de Azambuja; SANTOS, Luísa. A livraria da Fazenda Santa Cruz. In: ENGEMANN, Carlos; AMANTINO, Marcia. Santa Cruz: de legado dos jesuitas a pérola da Coroa. Rio de Janeiro: Eduerj, 2013. p. 145-179.

${ }^{4}$ RODRIGUES, Cláudia. Nas fronteiras do Além. A secularização da morte no Rio de Janeiro, séculos XVIII e XIX. Rio de Janeiro: Arquivo Nacional, 2005. p. 63.
} 
de devoção Mestre da vida que ensina a viver e morrer santamente, ${ }^{5}$ que foi escrito por João Franco $^{6}$ no século XVIII e mereceu várias reediçóes até o final do XIX.7

A ampliação da imprensa na Europa e do comércio de livros no Brasil, associada à rápida difusão das publicaçôes religiosas, fez com que as ideias de vida santa e de boa morte tivessem um maior alcance social. Os fiéis, em razão disso, tornaram-se cada vez mais convencidos de que deveriam possuir uma vida virtuosa e piedosa, preparando-se para a morte, livrando-se dos pecados, principalmente dos capitais, confessando-se e redigindo testamentos, sem esperar pelos momentos de enfermidade ou os "últimos instantes".

Neste artigo, nos detemos na análise da construção discursiva sobre os pecados capitais e as penas do inferno - que visava incutir a culpabilização nos leitores católicos — que o

${ }_{5}^{5}$ CASTRO [FRANCO], João de. Mestre da vida que ensina a viver e morrer santamente. Novamente correto por um religioso da ordem dos pregadores e oferecido à Virgem Santíssima do Rosário por mãos da sua prodigiosa imagem que se venera na vila do Barreiro. Nova edição. Lisboa: Editores Rolland \& Semiond, 1882. Publicado desde 1731, alcançou a vigésima edição ainda no século XVIII, em 1762. RODRIGUES, Cláudia. Nas fronteiras do Além, op. cit. p. 63. A primeira edição foi publicada em Lisboa pela oficina Augustiniana. SILVA, Innocêncio. Dicionario bibliographico portuguez. Estudos de Innocencio Francisco da Silva aplicáveis a Portugal e ao Brasil. Lisboa: Imprensa Nacional, 1859. T. III, p. 378. Este manual, publicado sob o formato "de livro de bolso", foi, certamente, muito mais acessível, por ser menos caro. De acordo com a historiadora Ana Cristina Araújo, o sucesso editorial que a obra obteve em Portugal, no século XVIII, superou as expectativas. A justificativa para as inúmeras reimpressóes pode estar na "virtude da obra", na "fama" e no "carisma do seu autor" que era um "pregador célebre". ARAÚJO, Ana Cristina. A morte em Lisboa: atitudes e representações, 1700-1830. Lisboa: Editorial Notícias, 1997. p. 164. Sua reimpressão por mais de 150 anos atendeu aos interesses da Igreja que, no século XIX, reafirmava seu discurso de autoridade sobre as práticas de leitura. CHARTIER, Roger. A aventura do livro: do leitor ao navegador. São Paulo: Ed. Unesp, 1999. p. 112-113.

${ }^{6}$ É possível que na edição de 1882 que consultamos os editores tenham confundido João Franco com João Baptista de Castro, daí o nome João de Castro. Todas as referências que encontramos ao autor de Mestre da vida, tanto em bibliotecas ibéricas, quanto em textos historiográficos ou literários, assinalam o nome João Franco, para as ediçóes do século XVIII. Então, por que a edição de 1882 assinala a autoria a João de Castro? Seria um equívoco, e neste caso, o João de Castro referenciado teria sido confundido com João Baptista de Castro? Esta é uma hipótese plausível, na medida em que, de acordo com o Dicionario bibliographico portuguez, de 1859, João Baptista de Castro (1700-1775) era padre, presbítero secular, beneficiado na Santa Igreja Patriarcal de Lisboa, vivendo por algum tempo em Roma. João Franco também era um religioso português, dominicano que teria professado a regra em 1704, tendo sido prior no Convento de Lisboa. O Dicionario aponta que Franco "vivia ainda em 1759", desconhecendo as datas de nascimento e morte. SILVA, Innocêncio. Dicionario bibliographico portuguez, op. cit. p.378. Portanto, além de serem contemporâneos um ao outro, ambos eram conterrâneos, religiosos e escritores que gozavam de prestígio e amplo reconhecimento do público letrado, católico e ilustrado da época. É possível, entâo, que no final do século XIX os nomes tenham sido confundidos. Feitas estas observaçóes, cabe ressaltar que neste artigo utilizaremos a referência a "Joáo Franco", embora o documento consultado assinale "João de Castro". SILVA, Innocêncio. Dicionario bibliographico portuguez, op. cit. Tomo III, p. 301, 378.

${ }^{7} \mathrm{O}$ exemplar do manual aqui analisado se encontra no acervo do Memorial Jesuíta da Universidade do Vale do Rio dos Sinos (Unisinos), RS. O exemplar utilizado neste artigo não informa o número da edição, possivelmente desconhecida pela oficina gráfica que o imprimiu. Esta observação torna-se mais bem fundamentada quando verificamos o relato do Dicionário bibliográfico que, ao enfatizar o sucesso editorial do manual, destacou existir continuamente a reprodução de "edições sucessivas, cuja enumeração, aliás, difícil de apurar, omito por desnecessária”. SILVA, Innocêncio. Dicionario bibliographico portuguez, op. cit. Tomo III, p. 379. ${ }^{8}$ RODRIGUES, Cláudia. Nas fronteiras do Além, op. cit. p. 63. 
manual evidencia, apontando para as possíveis leituras e, consequentemente, para a recepção que as orientaçóes elaboradas por João Franco tiveram, sobretudo, na Europa.

Apresentamos, inicialmente, o esforço da Igreja Católica que, ao longo do período moderno, difundiu a interiorização da culpa e a necessidade de confissão e penitência, bem como as recomendaçóes que João Franco faz para a "cura" do pecador, por meio do que denominou de "remédios" para a salvação. Para melhor compreender a circulação e a difusão de certas representaçóes dos pecados capitais, cotejamos as orientaçôes do dominicano Franco com algumas imagens que retratam os sofrimentos humanos daqueles que foram condenados ao inferno extraídas da obra Desengano dos pecadores, ${ }^{9}$ do jesuíta Alexandre Perier, ${ }^{10}$ também do século XVIII. Por fim, analisamos os discursos do padre português sobre as penas do inferno, bem como os recursos argumentativos empregados por Franco para estimular, no leitor, a interiorização da culpa, num exercício de autoconhecimento e autocrítica.

\footnotetext{
${ }^{9}$ A obra aqui citada data de 1724 e traz 14 discursos, resultado de suas atividades missionárias no Brasil, e se apresenta com a intenção de mostrar aos leitores os "tormentos" que perturbam o ser humano para, de alguma forma, afastá-los de seus vícios. Uma breve interpretação sobre essa obra, na sua terceira edição, de 1735, pode ser conferida no texto de STRIEDER, Inacio. Desengano dos pecadores, uma crítica social de 1735. Disponível em: <www.recantodasletras.com.br/artigos/2338332>. Acesso em: 24 mar. 2012. Interessante observar o parecer que frei Joaquim de Santa Ana e Silva, censor da Real Mesa Censória, emitiu sobre o livro, em 1771, e que apresenta uma perspectiva mais racional e cética: "Grande parte da obra é consagrada a descrever as penas infernais, com o fim de inspirar o temor no leitor. Um conjunto de estampas medonhas procurava aterrorizar o fiel, incutindo-lhe o medo do inferno. Neste caso, o parecer do censor revelou uma perspectiva que conciliava um propósito reformador, moderno, avesso às superstiçóes e aos fanatismos, com a preocupação sobre os efeitos das leituras diferenciadas que os leitores fariam dessas mesmas imagens. Ou seja, segundo frei Joaquim, enquanto 'o iletrado iria morrer de medo, o que podia despertar nele o fanatismo, o letrado consideraria tudo ridículo, o que conduziria ao ruir dos fundamentos da religiáo cristá'." Instituto de Investigação Científica Tropical, 2009. Disponível em: <www2.iict.pt/index.php?idc=6\&idi=15185>. Acesso em: 24 mar. 2012. O Dicionario bibliographico portuguez faz uma citação da referência completa da obra e nos dá indícios da sua recepção: "Desengano de Peccadores, necessario a todo o genero de pessoas, utilissimo aos missionarios, e aos pregadores desenganados, que só desejam a salvaçâo das almas. Composto em discursos morais. Roma na Off. De Antonio Rossi, 1724, 4ํㅡe XXX, 439 pág. A obra foi tão bem acolhida naquele tempo que teve logo uma segunda edição em Lisboa! Conquanto se não recomende pelo estilo, nem pela perspicuidade e pureza da linguagem, é todavia estimada de alguns (isto é, a edição romana) pelas quinze sofríveis gravuras que a acompanham, nas quais por modo esquisito se retratam os tormentos que no inferno padecem os condenados". SILVA, Innocêncio. Dicionario bibliographico portuguez. Lisboa: Imprensa Nacional, 1858. Tomo I, p. 39. Nota-se que, embora náo recomendada por religiosos, a obra foi bem aceita pelo público leitor, talvez curioso para tomar contato com as imagens do inferno.

${ }^{10}$ Padre jesuíta que atuou como missionário no Nordeste brasileiro entre o final do século XVII e início do século XVIII. Innocencio Francisco da Silva, autor do Dicionario bibliographico portuguez, refere-se a Alexandre Perier como um padre jesuíta, de nacionalidade desconhecida, que "por mais de trinta anos (segundo ele diz) missionou no Estado do Brasil". Desconhecendo as datas de nascimento e morte, o Dicionario assinala que "vivia em Roma a 14 de outubro de 1724", pois nesse dia assinou a dedicatória da sua obra, Desengano dos pecadores, ao cardeal Nuno da Cunha d'Ataíde. SILVA, Innocencio. Dicionario bibliographico portuguez, op. cit. Tomo I, p. 39.
} 


\section{Os manuais de devoção no século XVIII}

A literatura religiosa portuguesa, no século XVIII, proliferou tanto quanto aquela que se dedicava a outras temáticas - filosofia, teatro, romances, política, ciências naturais, contos, cartas e relatos - que também ganharam espaço nas livrarias e bibliotecas. ${ }^{11}$ Atendendo ao gosto dos leitores católicos, esses livros eram acessíveis e escritos em língua vulgar. ${ }^{12}$ Forneciam normas práticas de comportamento piedoso, contribuíam para uniformizar regras e preceitos de conduta e impunham a meditaçáo e o exercício da penitência, reforçando as preocupaçóes escatológicas da época. ${ }^{13}$

Comprovando a grande circulação deste gênero literário, Ana Cristina Araújo ${ }^{14}$ informa que, no espaço de 200 anos, foram produzidos 129 títulos — repartidos em 261 ediçóes —, sem contar os inúmeros títulos traduzidos do francês, do castelhano e do italiano. Entre os "manuais" e os "tratados de exercícios", estavam o Mestre da vida (1731) e o Desengano dos pecadores (1724), que refletiam a tendência "para transformar a mensagem de preparação da morte num espaço de reflexão global da vida cristã e num guia prático de bem viver". ${ }^{15}$

O manual Mestre da vida (1731) foi o grande sucesso de vendas no século XVIII, tanto que, ao chegar à sua oitava edição, no ano de 1747, segundo o Dicionario bibliographico portuguez, "dele se haviam vendido dezesseis mil exemplares", além das "contrafeições, que se haviam também feito em grande número, sem faculdade do autor" ${ }^{16}$ Essa informação é muito expressiva, pois indicativa do sucesso que este manual atingiu na sociedade portuguesa europeia e colonial, sendo inclusive motivo de contrafeição, imitação, falsificação ou plágio. A importância dessa informação não está na veracidade do número de exemplares vendidos, mas no indicativo de que o manual foi amplamente aceito e consumido pela sociedade letrada.

Contemporâneo ao manual Mestre da vida, o livro Desengano dos pecadores, do jesuíta Alexandre Perier, foi publicado, inicialmente, em Roma, em 1724, e reeditado dois anos depois, recebendo tradução em português. Segundo a historiadora Ana Cristina Araújo, ${ }^{17}$ houve pelo menos quatro ediçóes desta obra em Portugal. Na segunda metade do século XVIII, no entanto, a obra foi condenada pela Mesa Censória, ${ }^{18}$ que ordenou o recolhimento

\footnotetext{
${ }^{11}$ CHARTIER, Roger. Do palco à página: publicar teatro e ler romances na época moderna, séculos XVI-XVIII. Rio de Janeiro: Casa da Palavra, 2002. p. 98.

${ }^{12}$ ARAÚJO, Ana Cristina. A morte em Lisboa, op. cit. p. 147.

${ }^{13}$ Ibid, p. 148.

${ }^{14}$ Ibid., p. 149.

${ }^{15}$ Ibid., p. 152.

${ }^{16}$ SILVA, Innocêncio. Dicionario bibliographico portuguez, op. cit. Tomo III, p. 378.

${ }^{17}$ ARAÚJO, Ana Cristina. A morte em Lisboa, op. cit. p. 209.

${ }^{18}$ É possível, aqui, estabelecer um paralelo com a análise que o historiador Alain Corbin faz em relaçáo ao gosto humano pela praia em sua obra Território do vazio. CORBIN, Alain. Território do vazio: a praia e o imaginário ocidental. São Paulo: Companhia das Letras, 1989. As pinturas dos artistas mudavam à medida
} 
dos exemplares disponíveis "em atenção à doutrina" e devido "às ridículas estampas". Com objetivo de mostrar que os bens e os males da vida futura excediam os da vida presente, ${ }^{19} \mathrm{O}$ livro traz uma série de imagens ${ }^{20}$ que ilustram os sofrimentos da alma pecadora condenada ao inferno e à convivência eterna com os demônios. Para cada pecado capital há uma representação imagética correspondente, que visa a sensibilizar o leitor, comunicando-o sobre os horrores que atormentavam os pecadores enviados para o inferno. Pode-se dizer que a representação imagética era um importante recurso para ativar a imaginação dos leitores, atingindo também a indivíduos analfabetos ou semialfabetizados, convencendo-os sobre o necessário apego às virtudes cristâs.

As imagens apresentadas na obra de Perier antecediam cada um dos capítulos, predispondo o leitor à compreensão pretendida e à consequente ação almejada pelo autor. Todas as imagens ilustram um "tormento", o qual está relacionado com os cinco sentidos fundamentais (olfato, tato, visão, audição e paladar), agindo, portanto, sobre as sensibilidades dos indivíduos que estavam buscando o caminho da salvação por meio do manual. Em seu livro, o padre Perier explora a "terribilidade dos tormentos do Inferno", destacando ser esta a "principal matéria" do Desengano dos pecadores. ${ }^{21}$

Foi das suas experiências de missionário no Brasil e da tentativa de adaptar a escatologia a um nível mais imediato de comunicação que o padre Perier justificou as estampas presentes em sua obra. ${ }^{22}$ Seu trabalho de conversão dos indígenas parecia ser mais eficaz com o auxílio das imagens dos condenados:

Em trinta ou mais anos que estive no Brasil me sucederam muitos casos semelhantes. Tinha uma dessas imagens iluminada com a mesma cor de fogo. Não é crível a impressão do inferno que fazia nos índios, tanto assim que alguns vinham, já alta noite, a confessarem-se (...). Direi mais que nas missóes que eu fazia nas vilas e nos engenhos, por muito que eu estudasse de representar ao vivo os insofríveis tormentos eternos bem poucos e raros se moviam. Porém,

que a visão e o gosto em relação à praia alteravam-se e o mar ganhava uma conotaçáo positiva de prazer, lazer e descanso no século XVIII. Do mesmo modo, pode-se dizer que as percepçôes dos tormentos do Inferno podem ter se alterado a ponto de a sensibilidade religiosa da segunda metade do século XVIII — ou ao menos a dos grupos que representavam os censores — não mais aceitar aquelas representaçóes, repulsando as imagens aterradoras dos sofrimentos da alma no Inferno.

${ }^{19}$ ARAÚJO, Ana Cristina. A morte em Lisboa, op. cit. p. 156.

${ }^{20}$ Todas as imagens ilustram demônios, em maior ou menor proporção, com feiçóes humanas e características animalescas, e o pecador, com expressóes de angústia, medo ou desespero, sendo torturado com instrumentos cortantes ou perfuradores ou ainda por animais. Na época moderna, os homens atribuíam aos animais os impulsos que mais temiam em si mesmos, como a ferocidade, a gula e a sexualidade. THOMAS, Keith. O homem e o mundo natural. São Paulo: Companhia das Letras, 1988. p. 48, apud FLECK, Eliane Cristina Deckmann. Sentir, adoecer e morrer: sensibilidade e devoçáo no discurso missionário jesuítico do século XVII. Tese (doutorado em história) — Programa de Pós-Graduação em História, Pontifícia Universidade Católica do Rio Grande do Sul, Porto Alegre, 1999. p. 35.

${ }^{21}$ ARAÚJO, Ana Cristina. A morte em Lisboa, op. cit. p. 156.

${ }^{22}$ Ibid. 
eu mostrando do púlpito a imagem de um condenado, logo todo o auditório se desfazia em lágrimas e gemidos. ${ }^{23}$

Nesse sentido, é possível dizer que livrar os cristáos de todo e qualquer pecado e da possível condenação ao inferno era um dos objetivos fundamentais dos manuais de devoção católicos que circularam na Europa e na América entre o século XVIII e o XIX. Os discursos sobre os pecados capitais - cometidos pelo cristão que desobedecia ou contrariava as leis divinas - eram revestidos de tal gravidade que conduziam a alma aos sofrimentos do inferno. Tanto os pecados "de costume", quanto os pecados capitais eram entraves à salvação das almas no Juízo Final, ${ }^{24}$ e, para combatê-los, eram "receitados" alguns "remédios" para sua "cura", configurando assim o reforço de uma prática salvacionista da Igreja.

Em um período em que as crenças no Além mobilizavam os fiéis para a garantia de uma boa morte e o inevitável acerto de contas com Deus figurava nos testamentos dos homens e das mulheres mais devotos, publicaçôes religiosas - que instruíam os fiéis sobre os valores cristãos e sua doutrina - eram constantemente editadas, publicadas e consumidas pelos leitores católicos. Obras desse tipo, após serem editadas em Portugal, seguiam também para suas colônias, inclusive, para o Brasil. No século XIX, mesmo após a independência política do Brasil, o contato com Portugal permaneceu intenso, seja politicamente, através da relação entre a família imperial e a ex-metrópole, seja culturalmente, com a manutenção dos vínculos dos filhos de fazendeiros e latifundiários brasileiros com a universidade de Coimbra. Logo, não é difícil imaginar a profícua circulação literária que existia entre os países e sua conveniência aos brasileiros, ávidos por notícias e publicaçôes europeias. ${ }^{25}$

Durante o século XIX, a Igreja Católica se manteve vinculada ao Estado brasileiro, apesar de constantemente reclamar maior atenção do governo em relação aos assuntos eclesiásticos. Seguidora das orientaçóes emanadas de Roma, a hierarquia católica brasileira era formada nos poucos seminários existentes que, contudo, não deixavam de estar atentos às

\footnotetext{
${ }^{23}$ PERIER, Alexandre. Desengano dos pecadores, necessário a todo o gênero de pessoas, utilíssimo aos missionários e aos pregadores que só desejam a salvação das almas. Roma: Oficina Antônio Rossis na via do Seminário Romano, 1724. p. 24, apud ARAÚJO, Ana Cristina. A morte em Lisboa, op. cit. p. 158.

${ }^{24}$ Segundo Delumeau, o Juízo Final e a possibilidade de a alma ser condenada ao inferno foram, muitas vezes, representados por pinturas que destacavam as cores vermelho e preto, fogo e serpentes gigantes, causando uma "temível espera" nos vivos. DELUMEAU, Jean. O pecado e o medo: a culpabilização no ocidente (séculos XIII-XVIII). Bauru: Edusc, 2003. p. 334.

${ }^{25} \mathrm{O}$ início do século XIX foi de intensas práticas editoriais no Brasil que, conforme Lúcia Neves, contava com um ávido público consumidor, ao contrário do "que reconhece a historiografia tradicional, baseada exclusivamente em relatos de viajantes". Tal público era "formado por uma elite educada, com certeza, sob as mitigadas Luzes portuguesas, que crescera bastante com a transferência da Corte para o Brasil, mas cuja autonomia intelectual mostra-se bem mais difícil de avaliar". No Rio de Janeiro, na conjuntura do processo de independência do Brasil, já existiam nove livreiros especializados, de tal modo que "o gosto pelos livros intensificou-se, havendo uma diversificação das obras que aqui eram introduzidas”. NEVES, Lúcia Maria Bastos das. João Roberto Bourgeois e Paulo Martin, op. cit. p. 10.
} 
publicaçôes religiosas europeias. Já na Europa dos oitocentos, segundo Corbin, ${ }^{26}$ uma elite de católicos, que havia frequentado internatos religiosos ou seminários, lia maciçamente livros de piedade e entre as populaçóes fervorosas aprofundou-se a espiritualidade e a moral tridentina, que valorizava as expressôes de fé em torno do corpo de Cristo, do Sagrado Coração, da Virgem Maria e do Rosário. ${ }^{27}$

Aos leitores, portanto, o manual Mestre da vida apresentava-se não apenas como um roteiro de dogmas e de fé, mas, também, como um instrumento de divulgação de condutas e de valores cristáos que deveriam nortear a relaçáo dos sujeitos consigo mesmos e com os outros. ${ }^{28}$ Se o cristianismo impunha uma série de obrigaçôes, entre elas, a de "aceitar como verdade um conjunto de proposiçôes que constituem um dogma" e, também, o dever do cristão de saber "quem ele é" e "o que está acontecendo consigo", o manual — seguindo essas prerrogativas - incentivava o fiel a "saber as faltas que pode ter cometido" e "as tentaçôes às quais [se] está exposto". ${ }^{29}$

Em seu manual, João Franco faz várias consideraçóes para que os fiéis se livrassem dos pecados, de maneira a indicar comportamentos, atitudes e sentimentos que deveriam ser preservados, exercitados ou refletidos. A dor, o martírio, o sofrimento eram meios necessários para o expurgo dos pecados, mas deviam ser acompanhados da consciência de culpa e do arrependimento, como veremos ao longo do texto. Seguindo a doutrina cristá, os católicos deveriam conhecer suas fraquezas e evitar ou eliminar seus pecados. Receber os sacramentos e levar uma vida religiosa regrada eram importantes medidas a serem adotadas pelos fiéis. ${ }^{30}$

${ }^{26}$ CORBIN, Alain. A influência da religião. In: CORBIN, Alain; COURTINE, Jean-Jacques; VIGARELLO, Georges (Org.). História do corpo: da Revolução à Grande Guerra. Petrópolis: Vozes, 2008. p. 57-100, p. 57.

${ }^{27}$ Ibid., p. 60.

${ }^{28}$ PRADO FILHO, Kleber. Uma genealogia das práticas de confissão no Ocidente. In: RAGO, Margareth; VEIGA-NETO, Alfredo (Org.). Figuras de Foucault. Belo Horizonte: Autêntica, 2008. p. 139-146, p. 139.

${ }^{29}$ FOUCAULT, Michel. Do governo dos vivos: curso no Collège de France, 1979-1980: excertos. Organizaçáo de Nildo Avelino. São Paulo: Centro de Cultura Social; Rio de Janeiro: Achiamé, 2011. p. 168.

${ }^{30}$ Interessante perceber que, nos setecentos, os missionários jesuítas, em seu trabalho de evangelização na América, procuraram difundir formas de "bien morir" entre os indígenas guaranis concentrados nas reduçôes que ergueram na região platina. Segundo a historiadora Eliane Fleck, esta "boa morte” estava vinculada à necessidade da administração dos sacramentos do batismo, da confissão, da extrema-unção e do viático, fundamentais para amenizar o medo da morte e a ameaça da não salvação. Entre o século XVII e o XVIII, a Igreja se empenhou em perpetuar o medo, que pode ser definido como "uma emoção, uma afeição negativa, acompanhada de sofrimento e engendrada por alguma coisa ligada ao futuro, ao que vai acontecer e ao que pode acontecer. Sentir medo é um desconforto em relação à ideia de sofrimento futuro, de um sentimento negativo futuro. WOLFF, Francis. Devemos temer a morte? In: NOVAES, Adauto. Ensaios sobre o medo. São Paulo: Editora Senac, 2007. p. 17-38, p. 19-20. Portanto, neste período, o discurso eclesiástico recomendava a recorrência aos sacramentos que absolveriam o pecador trazendo-lhe o perdão, pois "morrer pecador significava ir para o Inferno, onde a alma sofreria eternos suplícios", e "morrer sem estar em pecado mortal facilitava a ajuda dos santos e do anjo da guarda na salvação da alma”. FLECK, Eliane. Sentir, adoecer e morrer, op. cit. p. 280. Tal discurso pode ser compreendido também a partir da consideraçáo de que, no Cristianismo, "tradicionalmente, a esperança cristá mais intensa estava na sobrevivência depois da morte e na recompensa celeste pelos méritos acumulados durante a vida", de tal modo que "simetricamente, o demérito acarretava 
Em relação aos pecados, o manual orientava os sujeitos a estabelecerem uma relação consigo, a descobrir-se, a decifrar-se e a conhecer-se. Ao tomar contato com os perigos inerentes a uma vida pecadora, o fiel deveria transformar sua consciência, ${ }^{31}$ tornando-a seu próprio vigilante, um revelador de si mesmo. O dominicano João Franco enfatizava a delimitação de estilos de vida, bem como a necessidade de o cristão examinar sua consciência, rememorar seus erros, para identificar suas práticas pecadoras, sentindo-se culpado e arrependido, buscando o perdão e a absolvição através da confissão $0^{32}$ e da penitência.

O sucesso desses manuais de devoção - confirmado em suas inúmeras ediçốes — demonstra a procura por esse tipo de literatura que, certamente, ocupava as prateleiras das bibliotecas de instituiçôes públicas e privadas. ${ }^{33}$ Utilizados na formação dos quadros eclesiásticos e na orientação dos fiéis católicos, esses manuais eram lidos e relidos, sendo recitados e conhecidos de cor, ${ }^{34}$ revelando uma maneira "intensa" de ler, "fortemente marcada pelo sagrado e [que] submetia o leitor à autoridade do texto". 35

Mesmo assim, é importante considerar as palavras de Michel de Certeau sobre a subjetividade da leitura e de suas múltiplas possibilidades:

Longe de serem escritores, fundadores de um lugar próprio, herdeiros dos servos de antigamente, mas agora trabalhando no solo da linguagem, cavadores de poços e construtores de casas, os leitores são viajantes; circulam nas terras alheias, nômades caçando por conta própria através

a punição no inferno”. ELIADE, Mircea; COULIANO, Ioan. Dicionário das religióes. Tradução de Ivone Benedetti. 2. ed. São Paulo: Martins Fontes, 1999. p. 127.

${ }^{31}$ Ao final do livro de Alexandre Perier, encontra-se um "Índice das cousas mais notáveis". Entre os conceitos apresentados está o de "consciência". Para ele, a consciência seria "um ditame da razão, um juízo prático, por meio do qual o homem discerne o bem do mal, e conhece o que deve seguir ou fugir. Basta ser homem racional para sentir em si complacência em obrando bem, e tristeza e medo, em tendo obrado mal". PERIER, Alexandre. Desengano dos pecadores, op. cit.

${ }^{32}$ Outro manual religioso - de confissáo - que, assim como Mestre da vida, circulou entre os séculos XVIII e XIX é o do espanhol Manuel de Arceniaga, intitulado Método practico de hacer fructuosamente confesion general de muchos anos, útil para confesores, y penitentes por quanto se proponen, y resuelven los casos mas frequentes que llegan al confesonario. 3. impr. Madri: Imprenta de Ramon Ruiz, 1894. A historiadora Mary Del Priore se valeu desse manual para demonstrar a condenação do aborto pela Igreja Católica, as puniçóes que eram aplicadas aos praticantes - que previam penitências que se estendiam por até cinco anos — e a recepção dessas teses moralistas cristãs através de manuais como este que data de 1724. PRIORE, Mary Del. Ao sul do corpo. Condiçâo feminina, maternidades e mentalidades no Brasil Colônia. Rio de Janeiro: José Olympio, 1993. p. $297,342$.

${ }^{33} \mathrm{O}$ século XVIII despontou, em Portugal, como de inúmeras possibilidades de leitura e de intensas relações entre Igreja e Estado. D. João V (1706-1750) assinou concordata com o Papa Bento XIV (1740-1758), o qual lhe concedeu o título de Rei Fidelíssimo. Ainda sob seu reinado, foi fundada a Academia Real de Biblioteca Portuguesa, cujos membros publicaram obras de memórias, dicionários, história, geografia e ciências.

${ }^{34}$ CHARTIER, Roger. Do palco à página, op. cit. p. 108.

${ }^{35}$ Segundo Chartier, a leitura "intensiva" seria aplicada até meados do século XVIII. A partir daí, surgiria o leitor "extensivo", que lia muitos textos, com rapidez, numa leitura "livre, individual e irreverente" e, raramente, os retomava. Ibid. No caso do manual, por ser obra voltada para a conversão, para o estudo e a meditação, muito provavelmente, sua leitura haveria de continuar sendo "intensiva". 
dos campos que não escreveram, arrebatando os bens do Egito para usufruí-los. A escritura acumula, estoca, resiste ao tempo pelo estabelecimento de um lugar e multiplica sua produçáo pelo expansionismo da reprodução. A leitura não tem garantias contra o desgaste do tempo (a gente se esquece e esquece), ela náo conserva ou conserva mal a sua posse, e cada um dos lugares por onde ela passa é repetição do paraíso perdido. ${ }^{36}$

As várias republicaçóes da obra aqui analisada sugerem que foram diversas as leituras realizadas ao longo do tempo. Os interesses, as interpretações, as apropriações e o entendimento certamente não foram os mesmos entre os leitores do século XVIII e os do XIX. Certeau $^{37}$ chama a atenção para a dinamicidade da leitura e para o provisório da criação e do interesse social em cada ocasião e contexto. É preciso também considerar que há uma distância entre a apropriação, o uso e interpretação feita por leitores e o sentido atribuído ao texto pelo autor ou editor.

Como bem destacou Certeau, os leitores passam pelo escrito, são viajantes, atribuem significaçóes plurais, usufruem e são suscetíveis ao esquecimento. $\mathrm{O}$ texto muda, se ordenando conforme os códigos de percepção do leitor. Poder-se-ia, então, dizer que a atribuição de significados é uma corrente em movimento, pois a leitura não está inscrita no texto, por isso neste artigo reconstituímos as possibilidades de recepção do texto a partir do contexto. ${ }^{38}$

As diversas possibilidades de leitura, somadas à circulação em diferentes momentos e por diferentes espaços, nos levam a crer que o manual Mestre da vida - apesar das transformações que atitudes, valores e comportamentos cristãos tenham sofrido ao longo do tempo - se manteve como guia espiritual importante para promover a efetiva interiorização de normas de conduta e de sensibilidades religiosas ${ }^{39}$ valorizadas pela Igreja Católica. ${ }^{40}$

Considerando, especificamente, a análise que faremos das recomendaçóes que o manual de devoção Mestre da vida traz para o combate aos pecados considerados capitais pela Igreja Católica, bem como das estratégias discursivas utilizadas por seu autor para promover a interiorização da culpa e o arrependimento em seus prováveis leitores, apresentamos, na

\footnotetext{
${ }^{36}$ CERTEAU, Michel de. A invenção do cotidiano: 1. As artes de fazer. Petrópolis: Vozes, 1994. p. 269-270, grifo nosso.

${ }^{37}$ Ibid.

${ }^{38}$ Reflexôes a partir do texto de CERTEAU, Michel de. A invenção do cotidiano, op. cit. p. 262-273; e de CHARTIER, Roger; CAVALLO, Guiglielmo (Org.). História da leitura no mundo ocidental, op. cit. p. 5, 6.

${ }^{39}$ As sensibilidades são "práticas situadas em jogos de relações sociais e negociaçóes de poder", portanto, não são apenas experiências internas, subjetivas e privadas, mas também discursos emotivos com efeitos externos, traduzidos e evidenciados materialmente a partir da reação que provocam nos sujeitos. FLECK, Eliane Cristina Deckmann. Cartografia da sensibilidade: a arte de viver no campo do outro (Brasil, séculos XVI e XVII). In: ERTZOGUE, Mariana; PARENTE, Temis (Org.). História e sensibilidade. Brasília: Paralelo 15, 2006. p. 217-248, 218-219.

${ }^{40}$ FLECK, Eliane Cristina Deckmann; DILLMANN, Mauro. "A Vossa graça nos nossos sentimentos": a devoção à Virgem como garantia da salvação das almas em um manual de devoção do século XVIII. Revista Brasileira de História, São Paulo, v. 32, n. 63, p. 83-118, jan./jun. 2012.
} 
continuidade, o entendimento que a Igreja Católica tinha sobre os pecados capitais no século XVIII.

\section{Os pecados capitais na moral cristã ocidental}

Os conceitos cristãos de pecado, culpa, confissão e penitência acompanharam a própria história da Igreja e não é nossa intenção aqui dar conta dessa historicização e de seus diferentes significados em diferentes contextos, mas, sim, destacar o quanto os discursos sobre os pecados capitais estiveram, no Ocidente, ligados ao de culpabilização, tendo alcançado o século XVIII, ${ }^{41}$ período em que o manual Mestre da vida foi publicado e circulou pela primeira vez.

Desde a Idade Média, a Igreja instituiu a obrigatoriedade de o cristão realizar a confissão de seus pecados, para o recebimento do perdáo, mediante exame de consciência sobre todas as circunstâncias da ação pecadora, o que implicava refletir "quem peca, qual é o pecado, onde pecou, quantas vezes pecou, com quem e contra quem cometeu, a razáo de ter cometido, como pecou e quando pecou". ${ }^{42}$

A confissão estava ligada ao sacramento da penitência ${ }^{43}$ tanto que, segundo Duby, ${ }^{44}$ no século XI, quando se elaboravam as modalidades de administração da penitência, os padres deveriam forçar os pecadores à confissáo e submetê-los à tortura, para que reconhecessem suas faltas e sentissem vergonha. Ainda nesse período, muitos "manuais de confissão" foram escritos e, "na maioria das vezes, susceptíveis de uma dupla utilização, pelo padre e pelo fiel". Sua função era a de ensinar, didaticamente, como administrar e receber a penitência, sendo o "exame de consciência" um plano obrigatório. ${ }^{45}$ Esse exame era "conduzido por referência aos sete pecados capitais, aos dez mandamentos, aos cinco sentidos", ${ }^{46}$ de modo que a reflexão penitencial buscasse circunstâncias agravantes do pecado e pontos de vista que conside-

\footnotetext{
${ }^{41}$ DELUMEAU, Jean. O pecado e o medo, op. cit.

${ }^{42}$ LOPES, Bárbara Macagnan. A confissão e os pecados capitais no Portugal do fim do século XV ao início do XVI. Revista Historiador, ano 3, n. 1, p. 123, jul. 2010. Disponível em: <www.historialivre.com/revistahistoriador>. Acesso em: 22 mar. 2012.

${ }^{43} \mathrm{O}$ sacramento da penitência implica o arrependimento dos fiéis diante dos pecados cometidos, podendo se manifestar internamente, através da dor sentida ou, externamente, mediante a aplicação de castigos ao corpo ou de privaçôes, como jejuns.

${ }^{44}$ DUBY, Georges. Eva e os padres: damas do século XII. São Paulo: Companhia das Letras, 2001. p. 19.

${ }^{45}$ Manuais de confissão tiveram longa duração na história da Igreja, como nos mostram ROUILLARD, Philippe. História da penitência: das origens aos nossos dias. Sáo Paulo: Paulus, 1999. p. 69; e DELUMEAU, Jean. O pecado e o medo, op. cit. p. 385.

${ }^{46}$ DELUMEAU, Jean. O pecado e o medo, op. cit. p. 381. Foi no período medieval que se fixou o setenário dos pecados capitais. A literatura espiritual utilizará esse número, destacando as sete obras de misericórdia, os setes salmos da penitência, as sete horas canônicas etc. Na literatura, o sangue divino das sete chagas lavaria os sete pecados. $\mathrm{Na}$ arte, as sete dores da Virgem apagariam os sete pecados capitais. Ibid., p. 366. Sobre a devoção à Virgem como recurso cristão salvacionista, ver FLECK, Eliane Cristina Deckmann; DILLMANN, Mauro. "A Vossa graça nos nossos sentimentos", op. cit.
} 
rassem as faltas cometidas, que estavam ligadas ao descumprimento ou ao descuido com os mandamentos de Deus e às atitudes excessivas, abusivas ou exageradas no uso dos sentidos.

Para justificar sua vontade de obter a salvação e para livrar-se do seu corpo pecador, o fiel deveria passar, necessariamente, por alguma forma de penitência, ou por uma autoflagelação - o castigo da carne - ou pelo martírio, buscando imitar a vida e os atos de Cristo. Logo, a salvação viria somente a partir de alguma penitência, prática largamente empregada tanto por religiosos, quanto por fiéis, como se pode constatar, por exemplo, nas Cartas Ânuas do século XVII, nas quais os missionários jesuítas que atuavam entre os indígenas sul-americanos destacam os seus efeitos sob a forma de bênçãos divinas e de "salubridad" nas reduçôes. ${ }^{47}$

De toda forma, o inferno continuava uma ameaça para aqueles que reincidiam nos pecados capitais e não seguiam as instruçóes da Igreja. No século XVIII, eram considerados pecados capitais ${ }^{48}$ a avareza, a gula, a inveja, a luxúria, a soberba, a preguiça e a ira, pois eram tidos como faltas graves, que mereciam a pena de morte ou capital, por serem gestadas pelas desordens das paixóes ${ }^{49}$ ou pelos instintos desordenados. ${ }^{50}$

$\mathrm{Na}$ época moderna, a Igreja reforçou sua doutrina por meio de publicaçóes e de campanhas de conversão religiosa, chegando ao século XVIII plenamente segura quanto ao discurso a ser empregado para a garantia de comportamentos e condutas morais que observassem

\footnotetext{
${ }^{47}$ FLECK, Eliane Cristina Deckmann. Almas em busca de salvação: sensibilidade barroca no discurso jesuítico (século XVII). Revista Brasileira de História, São Paulo, v. 24, n. 48, p. 255-300, 2004. Eliane Fleck constatou que os missionários jesuítas incutiam medo e horror nos nativos, com visóes aterradoras do Inferno, capazes de ocasionar "a internalização da permanente ameaça de experimentá-lo concretamente". De acordo com os relatos dos missionários, a internalização da noção de pecado e de culpa pelos indígenas ficava atestada nas penitências, flagelaçóes e confissóes, procedimentos que pareciam confirmar seu arrependimento e a busca pela salvação FLECK, Eliane Cristina Deckmann. O domínio das almas e o controle dos corpos, Revista Universum, n. 22, v. 2, p. 70-87, 2007; e FLECK, Eliane. Sentir, adoecer e morrer, op. cit. p. 255-256. ${ }^{48}$ Existem diferentes classificações e interpretaçôes sobre os sete pecados capitais. Segundo Thais Succi, "na Bíblia, os pecados capitais são: soberba, avareza, luxúria, ira, intemperança, inveja, acídia. (...) De acordo com a Suma Teológica de Tomás de Aquino, os sete seriam: vaidade, avareza, inveja, ira, luxúria, gula e acídia. Para outros teóricos do pecado, a soberba é tomada pela vaidade, a gula pela intemperança e a preguiça pela acídia. Encontramos também, em outras obras, a concomitância de duas ou mais denominaçóes para o mesmo pecado, como é o caso da vaidade e da soberba; ou pecados que seriam normalmente derivados, considerados capitais." SUCCI, Thais Marini. Os provérbios relativos aos sete pecados capitais. Dissertação (mestrado em estudos linguísticos) - Universidade Estadual Paulista "Júlio de Mesquita Filho", São Paulo, 2006. p. 68. Ver também DELUMEAU, Jean. O pecado e o medo, op. cit. p. 358-366. Os pecados capitais trazidos pelo manual Mestre da vida condizem com os adotados pelo Catecismo da Igreja Católica atualmente.

${ }^{49}$ Entre o século XV e o XVI, os pecados capitais serviram de inspiração para o artista Jerônimo Bosch, que buscou cenas da vida cotidiana e compôs suas obras com imagens que representavam os homens no auge de seus vícios e temores. SEBASTIÁN, Santiago. La iconografía del pecado. In: LOZANO, José et al. Pecado, poder y sociedad en la historia. Valladolid: Instituto de Historia Simancas, 1992. p. 63-104, p. 74. Os sete pecados capitais também estiveram presentes na obra de Dante Alighieri (1265-1321), Divina comédia, um clássico poema da literatura italiana, escrito no século XIV, que se divide em três partes, Inferno, Purgatório e Paraíso.

${ }^{50}$ SEBASTIÁN, Santiago. La iconografía del pecado, op. cit. p. 66.
} 
as leis de Deus. ${ }^{51}$ Tais discursos estavam ligados ao "medo de si" — dos próprios pecados, paixôes e tentaçôes —, que culminou na Europa, segundo Delumeau, ${ }^{52}$ entre o século XV e o XVIII, quando o pecado estava no centro da teologia cristá. O pecado seria uma oposição entre vontade do homem e vontade divina, manifestado por meio de atos exteriores, mas também por pensamentos e sentimentos. ${ }^{53}$

No século XVIII, os discursos sobre os pecados capitais se propagavam ${ }^{54}$ através dos escritos de religiosos que divulgavam a moral cristâ, por meio de publicaçóes que passaram a ser cada vez mais constantes: sermões, cartas, boletins, periódicos, manuais etc. Viver sem cair em pecado era a recomendação feita a todos os fiéis que desejassem "viver santamente". No manual aqui analisado, João Franco apresenta aos leitores, além dos exemplos de "exame particular de consciência", ${ }^{55}$ entendidos como meios para a obtenção da salvação, também os possíveis "remédios" contra as iniquidades humanas, sobre os quais trataremos na sequência.

\section{Os "remédios" para a eliminação dos pecados capitais}

O manual que analisamos não foi o único a alertar contra os pecados humanos, como se pode constatar no manual Breve aparelho e modo fácil para ensinar a bem morrer um cristão, de 1624, que instruía seus leitores acerca das tentaçôes diabólicas no momento da morte, entre elas, a soberba e a vaidade. ${ }^{56} \mathrm{Na}$ Idade Média, também o poeta espanhol Juan Ruiz destacava algumas proposiçôes para a superação das inclinações do ser humano ao pecado, entre as quais estava o uso das "faculdades del alma", como "memoria, entendimiento y voluntad". ${ }^{57}$

Aliás, os "remédios" "58 que João Franco propóe no manual Mestre da vida se aproximam das recomendaçôes feitas por outro dominicano, o venerável padre Granada, ${ }^{59}$ que viveu em

\footnotetext{
${ }^{51}$ FLECK, Eliane. Almas em busca de salvação, op. cit.

${ }^{52}$ DELUMEAU, Jean. O pecado e o medo, op. cit. p. 357.

53 Ibid., p. 358

${ }^{54}$ SEBASTIÁN, Santiago. La iconografía del pecado, op. cit. p. 94.

${ }^{55}$ FRANCO, João. Mestre da vida, op. cit. p. 13.

${ }^{56}$ RODRIGUES, Cláudia. Nas fronteiras do Além, op. cit. p. 65.

${ }^{57}$ SEBASTIÁN, Santiago. La iconografía del pecado, op. cit. p. 68.

${ }^{58}$ A menção que João Franco faz aos "remédios" contra os pecados já era feita por outros escritores, desde o período medieval, como se constata em Libro del buen amor, de Juan Ruiz (1284-1351), que indicava remédios para os pecados através do método da contraposiçáo. SEBASTIÁN, Santiago. La iconografía del pecado, op. cit. p. 68.

${ }^{59} \mathrm{O}$ padre Luís de Granada, também dominicano, autor de - entre outras obras - "Compêndio da doutrina Cristã" e "Guia de pecadores, e exortação à virtude", parece ter sido bastante admirado por João Franco, pois o Dicionario bibliographico portuguez, do final do século XIX, traz suas impressóes sobre Granada. Esse padre nasceu na Espanha em 1504, passando a maior parte de sua vida em Portugal, local de sua morte em 1588, a tal ponto de Franco destacar: "Podemos chamar-lhe nosso, porque entre nós viveu, ensinou e morreu”. SILVA, Innocencio. Dicionario Bibliographico Portuguez. Lisboa: Imprensa Nacional, 1860. Tomo V, p. 296. Jean Delumeau faz várias referências ao padre Luís de Granada em sua obra O pecado e o medo, v. II,
} 
Portugal no século XVI. Assim como para Granada, Franco defendia que a superação dos pecados, tidos como transgressóes às leis de Deus pela Igreja, podia se dar mediante uma vida de caridade, humildade, pobreza e pautada por virtudes morais ${ }^{60}$ ou, então, de virtudes que eram contrárias àquilo que os pecados representavam: diante da soberba, a humildade; da avareza, a generosidade; da luxúria, a castidade; da inveja, o desapego; da gula, a temperança; da ira, a serenidade; da preguiça, o trabalho. Pela via do contraexemplo, tinha-se aquilo que se devia evitar para não comprometer os modelos exemplares de atitudes e condutas do bom católico. ${ }^{61}$

O manual do dominicano Franco recomenda, primeiramente, a conscientização dos vivos sobre a importância de eliminar os pecados de suas vidas e seu convencimento sobre a necessidade de arrepender-se e de cultivar sentimentos de culpa. "Valer-se", "armar-se", "defender-se", "resistir", "fazer", "pelejar" são algumas das expressões utilizadas por Franco para suas recomendaçôes. Noções como a de "armar-se" e "pelejar" aparecem nas instruçôes de combate aos pecados da Avareza e da Inveja, evocando a utilizaçáo de fortes "armas" para sua "cura".

As imagens presentes na obra Desengano dos pecadores, somadas a outras representaçóes discursivas difundidas naquele contexto, podem nos ajudar a identificar as possíveis leituras e interpretaçóes sobre o inferno e a condenação das almas pecadoras correntes no período. No século XVIII, o missionário francês padre Santiago Bridaine, em seus sermôes, dizia: "Existe um inferno onde estâo mergulhados e enterrados todos os pecadores que morreram sem ter feito penitência, os blasfemadores, as falsas testemunhas, os vingativos, os ladrôes, os maledicentes, os bêbedos". A essa listagem de pecadores, o padre acrescentava que aqueles "que caem nele em maior número e que são terrivelmente atormentados são, sem contestação, os impudentes", ${ }^{62}$ ou seja, os destituídos de pudores, numa sutil referência aos luxuriosos.

$\mathrm{Na}$ continuidade, relacionamos as representaçôes desses "tormentos" - evidenciadas nas ilustraçôes que o livro de Alexandre Perier traz — com os "remédios" que João Franco propóe para cada um dos sete pecados capitais.

Iniciamos com a soberba, considerada por Franco a "raiz" de todos os pecados, como o "apetite da própria excelência". Contra esse "vício", Franco propóe a necessidade de compreensão de que o nascimento "é culpa", a vida é "miséria" e a morte, "corrupção": "considera que no teu nascimento foste uma matéria torpe, és agora um saco de imundícia e serás

especialmente no capítulo 15, "Pecado e pecados".

${ }^{60}$ FRANCO, João. Mestre da vida, op. cit. p. 93

${ }^{61}$ SEBASTIÁN, Santiago. La iconografía del pecado, op. cit. p. 68. Essa luta do bem contra o mal, da virtude contra o pecado, parece ser anterior à Idade Média, tanto que, já no século IV, o poeta espanhol Prudencio Clemente escreveu o poema que transcrevemos, fazendo um contraponto entre as virtudes e os pecados ou vícios: Fe contra Idolatría / Castidad contra Lujuria / Paciencia contra Ira / Humildad contra Soberbia / Sobriedad contra Molicie o Lascivia / Caridad contra Avaricia /Concordia contra Discordia Apud SEBASTIÁN, Santiago. La iconografía del pecado, op. cit. p. 67.

${ }^{62}$ Apud DELUMEAU, Jean. O pecado e o medo, op. cit. p. 212. 
depois manjar dos bichos". Se os Anjos, que resplandeciam como "estrelas", haviam sido considerados maus e "lançados no Inferno", o ser humano, sendo "pó e cinza", teria maiores possibilidades de condenação em função da soberba. Se Deus "castigou aos Anjos por um pensamento de soberba e ainda dura e durará eternamente a sua justa vingança, que posso eu esperar sendo soberbo?". ${ }^{63}$

A imagem "Tormento dos soberbos" apresenta o pecador diante do domínio exercido pelo demônio, mostrando sua fraqueza diante de rochas que o deixam imobilizado. As expressóes de dor e sofrimento apresentam um inegável apelo dramático e a provável intenção de causar impacto no leitor, num tempo — o século XVIII — em que o progresso médico-científico buscava justamente divulgar o aperfeiçoamento dos estudos sobre o corpo humano, do combate às doenças e às dores, dos valores higiênicos e da imagem de força física que promoviam a saúde e garantiam a vida.${ }^{64} \mathrm{~A}$ saúde e a disposição física, no entanto, de nada valeriam diante da fúria divina que condenava e se abatia sobre o pecador.

Figura 1

\section{Soberba}

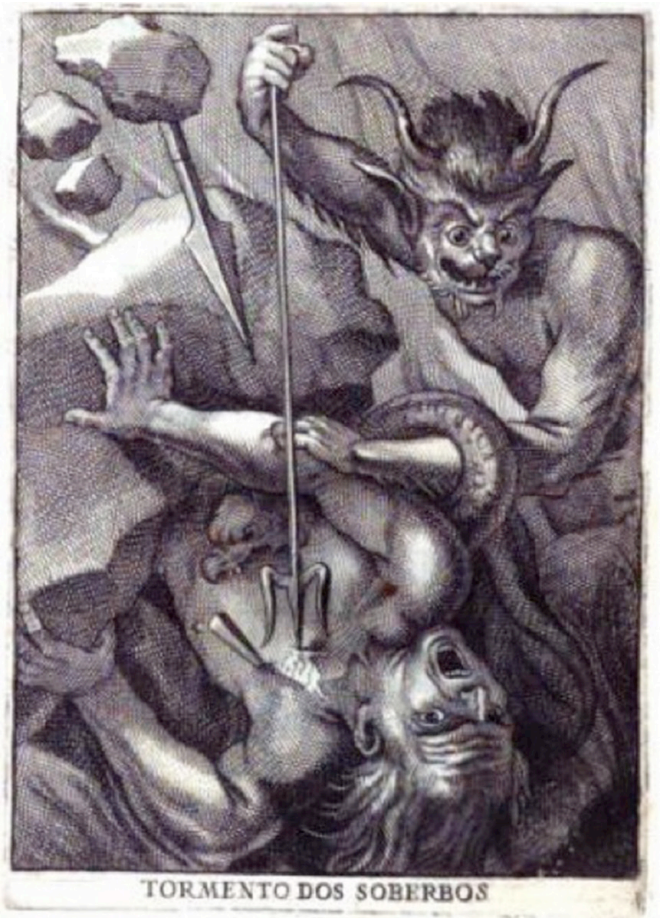

Fonte: PERIER, Alexandre. Desengano dos pecadores, op. cit.

\footnotetext{
${ }^{63}$ FRANCO, João. Mestre da Vida, op. cit. p. 92

${ }^{64}$ NUNES, Rossana Agostinho. Nas sombras da libertinagem: Francisco de Mello Franco (1757-1822) entre luzes e censura no mundo luso-brasileiro. Dissertação (mestrado em história) — Programa de Pós-graduação em História, Universidade Federal Fluminense, Niterói, 2011. p. 138.
} 
Quanto à avareza — o "desordenado desejo de riqueza" —, o manual destacava que o "remédio" era a reflexão sobre o desprezo de Deus às riquezas, que, ao descer "dos Céus à terra", nasceu "de uma virgem pobre e mui humilde", em um "presépio e sobre palhas", vivendo e amando a pobreza. O cuidado maior devia estar em não "perder" a "alma criada à imagem de Deus", por "vãos interesses mundanos". Estimar o ouro e a prata, tornando-se escravo da riqueza, seria "vergonha e vilania", pois para quem "professa a Lei de Cristo" e é seu discípulo, as verdadeiras riquezas seriam as "virtudes e a boa consciência". ${ }^{65}$ João Franco exemplifica o pecado da avareza a partir das riquezas de reis e rainhas "poderosas", recolhidos ao aconchego de palácios, ao conforto de camas "brandas", aos desejos de "interesses mundanos" voltados para a cobiça por ouro e prata, a ponto de se tornarem "escravos" dele.

A riqueza material não teria valor após a morte e, para o avarento condenado, a fortuna seria um meio de tortura. A imagem "Tormento dos avarentos" que o livro de Perier traz apresenta um demônio alado que, com satisfação, lança moedas sobre o pecador, que se encontra dominado por dragóes, que o imobilizam e o amordaçam. Se, por um lado, como destacou Ariès, ${ }^{66}$ os avarentos dos tempos modernos não desejavam separar-se de seus bens para levá-los consigo, por outro, havia algo de consolador na ameaça de condenação, pois, ao mesmo tempo que expunha a alma pecadora às torturas, náo a privava do seu tesouro.

Figura 2

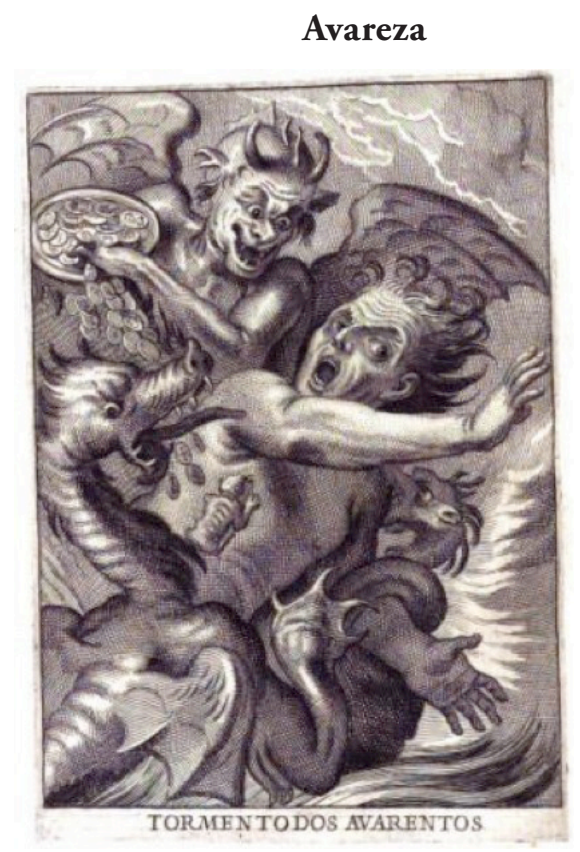

Fonte: PERIER, Alexandre. Desengano dos pecadores, op. cit.

\footnotetext{
${ }^{65}$ FRANCO, Joáo. Mestre da vida, op. cit. p. 93.

${ }^{66}$ ARIÈS, Philippe. O homem perante a morte. 2. ed. Lisboa: Publicaçôes Europa-América, 2000 [1977]. v. 1 , p. 158.
} 
Outro pecado a "manchar" a alma era a luxúria, "um desordenado apetite de sujos e desonestos deleites" ${ }^{67}$ Esse pecado, ligado aos prazeres carnais, foi considerado de grande culpabilidade pelo Catolicismo, pois profanava o corpo, tido como abrigo "[d]o corpo e sangue de Jesus Cristo".

Foi a partir da Contrarreforma que a Igreja tentou impor "regras meticulosas de exame de si mesmo", atribuindo grande importância às "insinuaçóes da carne: pensamentos, desejos, imaginaçóes voluptuosas, deleites". ${ }^{68}$ No século XVII, o corpo deveria estar subordinado à mente, já que o Cristianismo europeu considerava que os apetites e os desejos eram cegos, obstinados e, claro, pecaminosos. ${ }^{69}$ Antes disso, porém, no final do século XV, a luxúria já ocupava grande espaço nos tratados de confissáo portugueses, especialmente no Tratado de confisson, de 1489, obra que considerava a luxúria "tudo aquilo que é exagerado". ${ }^{70}$

Em se tratando da América portuguesa, os "vícios da carne" — o incesto, a poligamia, os concubinatos e a nudez - eram, segundo Laura de Mello e Souza, ${ }^{71}$ aqueles que mais se destacam nos relatos dos cronistas e dos padres jesuítas que se dedicavam à conversão dos indígenas. Se no século XVII a luxúria foi associada à condição animalesca, à bestialidade e à brutalidade, a partir do século XVIII, período em que foi publicado o manual, o sexo náo devia "ser mencionado sem prudência", fazendo da carne "a origem de todos os pecados". ${ }^{2}$ De acordo com Carneiro, ${ }^{73}$ além de ser tida como "o pior pecado", a luxúria "também será considerada como a mais adversa de todas as doenças. A noção do amor [nós diríamos sexo] como pecado capital é um dos fundamentos da moral cristâ". Já a historiadora Mary Del Priore demonstrou que, ao final do século XVIII, "a ideia de amor como enfermidade se consolidara, e a Igreja oferecia-se como 'médico da alma'”. Toda e qualquer paixão, sintoma da luxúria, seria perturbadora para o estado interior e exterior do ser humano, tirando-lhe a tranquilidade, levando a Igreja a restringir a sexualidade à privacidade do quarto e condenar

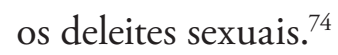

Fica evidente no manual a intenção de levar o pecador a assumir a culpa de maneira que

\footnotetext{
${ }^{67}$ FRANCO, João. Mestre da vida, op. cit. p. 94.

${ }^{68}$ FOUCAULT, Michel. História da sexualidade I: a vontade de saber. Rio de Janeiro: Ediçôes Graal, 1988. p. 25.

${ }^{69} \mathrm{O}$ corpo, enquanto "prisão da alma", facilmente ofende e comete "atos criminosos". Porém, "devido a sua verdadeira natureza (sendo imperfeito, até bestial) ele pode, parodoxalmente, ser prontamente desculpado (a fraqueza da carne)". Estas percepções das responsabilidades da mente e do corpo não se alteraram muito até o século XIX. PORTER, Roy. História do corpo. In: BURKE, Peter. A escrita da história: novas perspectivas. Sáo Paulo: Ed. Unesp, 1992. p. 291-326, 304, 305.

70 LOPES, Bárbara. A confissão e os pecados capitais no Portugal do fim do século XV ao início do XVI, op. cit. p. 128.

${ }^{71}$ SOUZA, Laura de Mello e. O diabo e a terra de Santa Cruz: feitiçaria e religiosidade popular no Brasil Colonial. 2. ed. São Paulo: Companhia das Letras, 2009 [1986]. p. 86.

${ }^{72}$ FOUCAULT, Michel. História da sexualidade, op. cit. p. 25.

${ }^{73}$ CARNEIRO, Henrique. Amor, sexo e moral médico-clerical na Época Moderna. Revista História, São Paulo, n. 132, p. 29-42, p. 39, jun. 1995.

${ }^{74}$ PRIORE, Mary Del. Ao sul do corpo, op. cit. p. 180-181.
} 
esta fique registrada no corpo do sujeito. Exclamava João Franco: "que maior culpa do que profanar a morada em que o mesmo Deus realmente há de habitar!". A luxúria traria inúmeros problemas, pois afetaria a vida do pecador com a diminuição das "forças do corpo", o aumento das enfermidades, o envelhecimento precoce, a "vida mais curta" e escândalos. ${ }^{75}$ A pureza, tão valorizada para uma vida santa, especialmente, para as mulheres, considerada a "flor de toda a formosura", seria, em função do pecado, reduzida à miséria e à corrupção, ao horror e à confusão. ${ }^{76}$

Figura 3

\section{Luxúria}

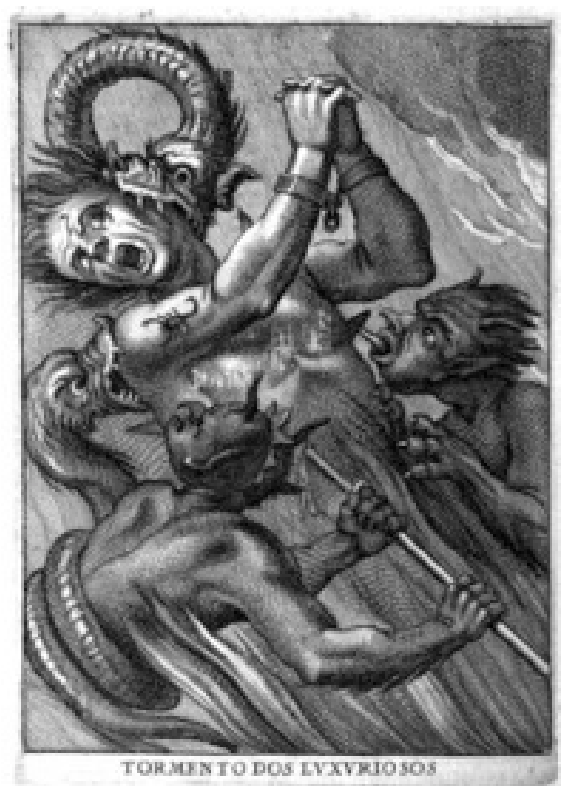

Fonte: PERIER, Alexandre. Desengano dos pecadores, op. cit.

A imagem "Tormento dos luxuriosos" mostra bem a dimensão repressiva associada a este pecado: o condenado, com os braços acorrentados, é atacado por dois demônios, um escorpião e duas serpentes, dos quais sofre arranhóes, perfuraçôes e mordidas — distintas formas de marcar agressivamente o corpo do sujeito pecador. O Novo Testamento faz referência a estes dois animais: "Eu lhes dei autoridade para pisarem sobre cobras e escorpiôes, e sobre

\footnotetext{
${ }^{75}$ Cabe lembrar que no século XVI havia todo um "esforço de modificaçáo de condutas morais e sensibilidades", a "educação do corpo era (...) um meio de educar a alma", pois "a exposição dos corpos não somente era inadmissível, do ponto de vista moral, como também era inadequada à civilizaçáo do espírito". FLECK, Eliane. Almas em busca de salvação, op. cit. p. 262.

${ }^{76}$ FRANCO, João. Mestre da vida, op. cit. p. 94.
} 
todo o poder do inimigo; nada lhes fará dano"..$^{77}$ As serpentes e os escorpiôes representam as maldades cometidas contra os seres humanos, animais que lançam venenos, concebem simbolicamente o mal, prendem o corpo e a alma, eliminam saúde e emoçóes. O próprio pecado original - que fez com que Adão e Eva conhecessem a morte no paraíso terrestre por terem comido do fruto proibido - foi associado a uma serpente, que passou a representar a tentação. O século XVII foi o período em que as "classes cultas" de vários países europeus se interessaram pelo pecado original, o que fez com que se difundisse em textos literários que destacavam a glória e, depois, a miséria dos homens. ${ }^{78}$

A inveja, por sua vez, era o pecado que tornava o homem semelhante aos demônios, por ser "uma tristeza dos bens alheios e pesar da felicidade dos outros". Os invejosos, "não querem que nós levantados do pó subamos ao lugar donde eles cairão", e assim o são "não porque pretendam alcançar a prosperidade dos outros", mas porque desejam "que todos fossem miseráveis como eles". A cura para esse pecado estaria na prática da caridade, expressa no desejo de conceder "para teus irmãos tudo quanto quererias para ti: não queiras para eles o mal que náo quererias para ti, refutando todos os seus proveitos como teus e chorando os pecados alheios como próprios". ${ }^{79}$

Se o invejoso cobiçava a riqueza e a beleza alheia, deveria, como se pode inferir da ilustração presente na obra de Perier, ser condenado à "pena do dano", privado da visão de Deus, ou seja, longe dos olhos do Criador, no inferno do inferno. Na imagem, Deus aparece ao longe, sentado em seu trono celestial, com o braço esquerdo erguido, como se estivesse desaprovando o pecador, que já se encontra no Inferno, e incentivando o demônio a vendá-lo. A venda posta sobre os olhos do pecador está diretamente relacionada à privação da visão, sentido que lhe facultava alimentar a inveja. No livro de Perier, a imagem vem acompanhada da explicação da condição extrema desse pecado: "Desejar com ansiedade, o que nunca há de ter, e odiar necessariamente, o que sempre há de desejar". ${ }^{80}$

Mas o invejoso era carregado de impulsos e de desejos de conquista da fortuna alheia. No Brasil Colônia, por exemplo, a ferocidade em busca de metais pode ser tomada como um caso do capital pecado da inveja. A cobiça, como também era chamada a inveja, acompanhou os portugueses no Brasil, constituindo-se, segundo relatos eclesiásticos, em um dos pecados de que mais padeciam os homens brancos, corroborando, assim, a ideia de que a colônia incitava à transgressão. Muitos deles arriscavam suas vidas, apesar da ameaça permanente dos ataques indígenas e das "onças bravas" e da companhia constante da fome, na busca pelos sonhados metais preciosos. ${ }^{81}$

\footnotetext{
${ }^{77}$ Lucas 10: 19, Disponível em: <www.bibliaon.com/versiculo/lucas_10_19/>. Acesso em: 23 jan. 2013.

${ }^{78}$ DELUMEAU, Jean. O pecado e o medo, op. cit. p. 471.

${ }^{79}$ FRANCO, João. Mestre da vida, op. cit. p. 96.

${ }^{80}$ PERIER, Alexandre. Desengano dos pecadores, op. cit. p. 343.

${ }^{81}$ SOUZA, Laura de Mello. O diabo e a terra de Santa Cruz, op. cit. p. 87.
} 
Figura 4

\section{Inveja}

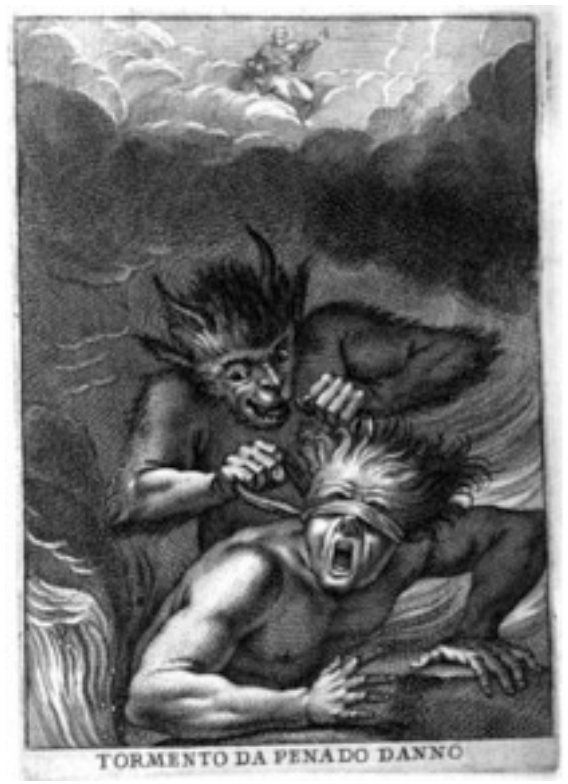

Fonte: PERIER, Alexandre. Desengano dos pecadores, op. cit.

Para triunfar diante de todas as paixóes era necessário vencer a luta contra o pecado da gula - "um desordenado desejo de comer e beber" —, pois dessa tentação "veio a morrer a todo o gênero humano". A gula seria, então, um inimigo interno a ser combatido, pois "só poderás sujeitar os inimigos de fora quando tiveres morto aos que nascem de ti mesmo". ${ }^{82}$ Nesse caso, é interessante perceber que, novamente, a culpa atua sobre o corpo do sujeito, pois contra este pecado havia a necessidade do jejum e da abstinência, à maneira de penitência e de ação sobre o corpo do pecador. Em Portugal e na Espanha setecentistas, o jejum era uma das práticas espirituais consolidadas, estando associado tanto com as práticas piedosas para alcançar indulgências e salvação das almas, quanto com a celebração da quaresma. ${ }^{83}$ De acordo com Franco, se Jesus "sofreu fomes por nós todos, quanto mais deves tu jejuar e padecê-las por ti mesmo?". ${ }^{84}$ À abundância de "mimos e regalos", contrapunha-se a escassez a que se submeteram "santos padres" sustentando-se com "raízes e ervas" por "quererem ir ao céu". Contra o deleite de fartar-se havia de se adquirir a temperança, o autodomínio e o controle de si. ${ }^{85}$ Essa era, sem dúvida, uma das razóes para que a Igreja repudiasse os prazeres

\footnotetext{
${ }^{82}$ FRANCO, João. Mestre da vida, op. cit. p. 95.

${ }^{83}$ LONDOÑO, Fernando Torres. Sob a autoridade do pastor e a sujeição da escrita: os bispos do sudeste do Brasil do século XVIII na documentação pastoral. História: Questóes \& Debates, Curitiba, n. 36, p. 161-188, p. $172,2002$.

${ }^{84}$ FRANCO, João. Mestre da vida, op. cit. p. 96.

${ }^{85}$ Ibid., p. 97.
} 
do corpo e condenasse a gula, pois a obesidade e a embriaguez — tida como a "sepultura da razão humana" ${ }^{86}$ - eram "um sinal visível deste pecado suscetível das chamas infernais" ${ }^{87}$

Na imagem "Tormento do gostar", animais peçonhentos são novamente evocados para representar o mal, o veneno, o trágico e a dor. Nela, o guloso é - por seu "desejo desordenado de comer e beber" - reprimido com a ingestão obrigatória de baratas, escorpióes, insetos e cobras. Para além desse castigo, o pecador é alvo de tortura por dois demônios e uma serpente, os quais ele tenta inutilmente afastar.

\section{Figura 5}

\section{Gula}

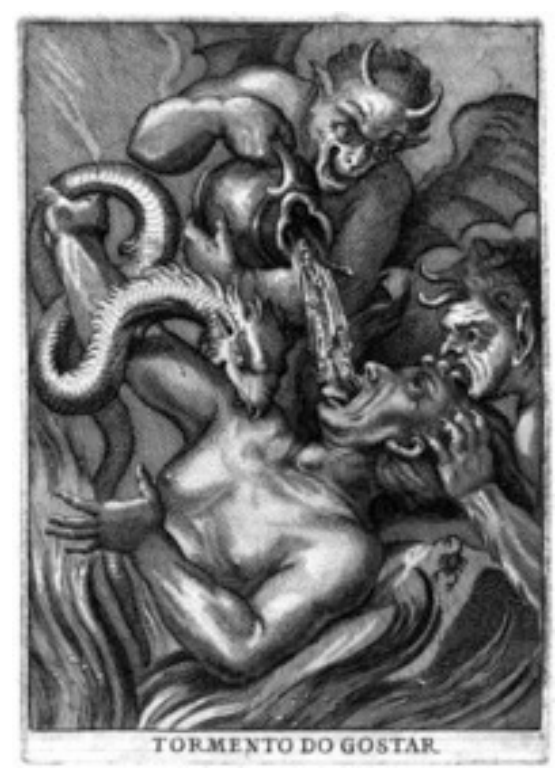

Fonte: PERIER, Alexandre. Desengano dos pecadores, op. cit.

De acordo com estudos recentes sobre a história da alimentação em Portugal, sabe-se que, além de doces, pães, batatas e vinhos, também feijão, arroz e grão-de-bico integravam a dieta lusitana. ${ }^{88}$ Se no século XVIII Portugal contava não apenas com uma diminuta população, mas também com uma agricultura deficitária, na América portuguesa, a mandioca, o milho e os feijōes tornavam-se a base da alimentação colonial. Pequenos produtores, roceiros, brancos pobres, pretos forros pagavam arrendamentos e favores aos senhores ou mesmo para ordens religiosas, fragilizando o grupo social produtor e gerando crises periódicas, com ocorrências de grandes fomes entre o final do século XVII e o século XVIII. ${ }^{89}$

\footnotetext{
${ }^{86}$ CARNEIRO, Henrique. Bebida, abstinência e temperança na história antiga e moderna. São Paulo: Senac, 2010. p. 194.

${ }^{87}$ RODRIGUES, Cláudia. Nas fronteiras do Além, op. cit. p. 51.

${ }^{88}$ CARNEIRO, Henrique. Bebida, abstinência e temperança na história antiga e moderna, op. cit. p. 168.

${ }^{89}$ SILVA, Francisco Carlos Teixeira. Conquista e colonização da América portuguesa — O Brasil Colônia,
} 
No Brasil, assim como na Europa, os dias festivos - momentos em que havia fartura de comidas e bebidas e, consequentemente, excessos - eram os mais propícios para que o pecado da gula fosse cometido. ${ }^{90}$ Nos jantares servidos para celebração das colheitas ou durante festas religiosas eram também consumidas - dependendo do status social dos indivíduos - guloseimas e iguarias importadas, acompanhadas de licores e refrescos. Eram, portanto, ocasióes em que, inevitavelmente, os fiéis eram incitados a transgredirem a moderação alimentar e a regrada ingestão de bebidas alcoólicas, entregando-se ao "desejo desordenado de comer e beber".

Em relação à ira — "um desordenado desejo de vingança contra aquele que julgamos nos ofendeu" - , era recomendado que o pecador se desse conta de que mesmo feras da natureza conservavam a paz entre os da sua espécie e "até os demônios, primeiros autores de toda a nossa discórdia, têm entre si a sua liga e de comum consentimento conservam sua tirania". Sentir ódios, estar envolvido em dissensóes e divergências constituía em bloqueio contra o oferecimento de sacrifícios a Deus, ao qual só seria possível agradar estando em "conformidade de coração". ${ }^{11}$ Franco recorre ao evangelho de Mateus para recomendar: "reconciliar-te primeiro com teu irmão". Diante da ira, o conselho era sossegar e dar "tempo a que se aplaque a cólera", rezando "uma ou mais vezes a oração do padre nosso". ${ }^{2}$

Já a imagem "Tormento dos tiranos e vingativos" faz referência à fúria, e mostra demônios torturando a um pecador com um punhal, com a própria língua - que lhe perfura o peito - e com o auxílio de serpentes. A ira é, entre os pecados capitais, o que mais remete às intervençôes demoníacas, tanto que as mulheres acusadas de feitiçaria pela Inquisição eram descritas como possuídas por demônios. ${ }^{93} \mathrm{Na}$ imagem, percebe-se que eles atingem o peito do pecador na altura do coração, o órgão que simbolicamente representa o cultivo dos sentimentos humanos.

1500/1750. In: LYNHARES, Maria Yeda et al. (Org.). História geral do Brasil. 9. ed. Rio de Janeiro: Elsevier, 1990. p. 33-94, 72-73.

${ }^{90}$ PRIORE, Mary Del. Festas e utopias no Brasil Colonial. São Paulo: Brasiliense, 1994. p. 67-69.

${ }^{91}$ Neste caso, a oração e a meditação sobre as benesses do Céu e os malefícios do inferno propostas por Franco, em 1731, podem ser comparadas aos Exercícios espirituais adotados pelos jesuítas desde o século XVI, e "que induziam o praticante das meditaçôes a experimentar visôes e sensaçóes que materializavam o céu e o inferno”. FLECK, Eliane. O domínio das almas, op. cit. p.77.

${ }^{92}$ FRANCO, João. Mestre da vida, op. cit. p. 98.

${ }^{3}$ SOUZA, Laura de Mello. O diabo e a terra de Santa Cruz, op. cit. p. 340. 


\section{Figura 6}

Ira

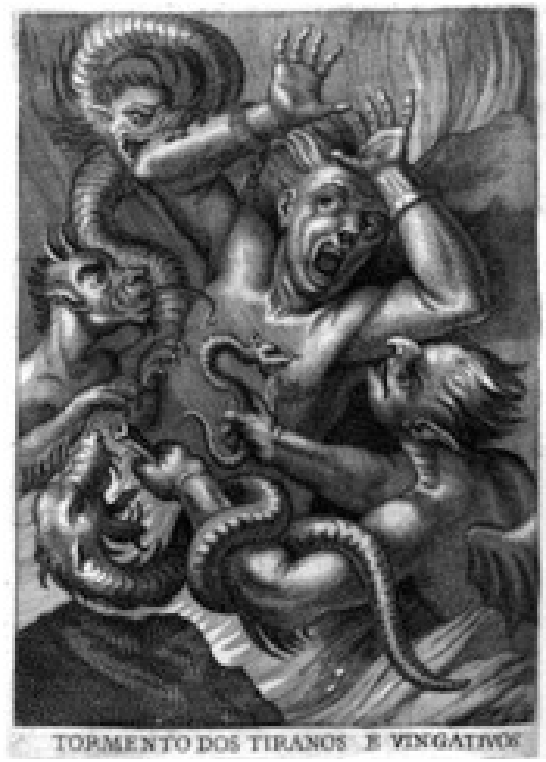

Fonte: PERIER, Alexandre. Desengano dos pecadores, op. cit.

Já a preguiça — o sétimo dos pecados capitais — era definida como "uma frouxidão do coraçấo para obrar bem e um fastio das cousas espirituais", que se manifestava no coração humano, diante da qual o cristáo deveria considerar os sofrimentos de Cristo que "andava pregando, ensinando e curando". A grande questão era: "se Deus trabalhou tanto pela salvação alheia, quanto deves tu trabalhar pela tua própria?”. O esforço deveria ser impresso no corpo, na atividade, no sofrimento e nos "suores", como foram os trabalhos de Cristo, dos apóstolos, dos mártires, dos confessores, das virgens, dos santos e, até mesmo, da natureza. ${ }^{94}$ Tais trabalhos consistiam nas orações incessantes, na pregação e nos ensinamentos das matérias da fé e, sobretudo, na defesa da Igreja Católica. A natureza também era um espelho para o preguiçoso, uma vez que os astros - o Sol, a Lua e as estrelas - trabalhavam sem cessar para servir aos homens, bem como as plantas e os animais, que cresciam e trabalhavam para o proveito humano. Tida como conduta social e religiosa condenável, a preguiça também foi constantemente referida pelas autoridades metropolitanas e pelos missionários enviados para as áreas de colonização. ${ }^{95}$ Evidenciando a condenaçấo dessa apatia e da indisposição para o

\footnotetext{
${ }^{94}$ FRANCO, João. Mestre da vida, op. cit. p.99.

${ }^{95}$ Esta percepção repercutiu de forma significativa na produção historiográfica e literária brasileira, como se constata na obra de Paulo Prado, Retrato do Brasil: ensaio sobre a tristeza brasileira, escrita na década de 1920, na qual o escritor endossava a ideia de que os nativos sul-americanos passavam muito tempo deitados em redes e eram indolentes. SOUZA, Laura de Mello. O diabo e a terra de Santa Cruz, op. cit. p. 87.
} 
trabalho — enxergada sempre com maior nitidez no "Outro" —, a imagem "Tormento do sítio imóvel”, do livro do padre Perier, remete ao pecado da preguiça e condena o pecador à imobilidade eterna da alma, que é cravada ao solo, mediante violentas perfuraçôes em seu corpo, que a impedem de gozar livremente das bem-aventuranças do Paraíso.

Entre os remédios indicados por João Franco para curar imperfeiçóes e livrar-se dos pecados capitais, destacam-se a necessidade de conscientização da culpa, de sofrimento e esforço, de compreensão da situação da alma no Além e da necessidade de abnegação e arrependimento. Essas instruçóes iniciais apresentadas aos leitores, orientadas por uma pedagogia de bem viver, pressupóem a conscientização dos benefícios de uma vida longe dos pecados, e vinham acompanhadas, na sequência das páginas do manual, de agressivas ameaças, a partir de interpretaçóes sobre um tenebroso inferno ${ }^{96}$ capazes de gerar aceitação do discurso da culpabilidade. Vejamos, então, qual era a visão sobre as penas do Inferno que o manual de João Franco pretendia difundir.

Figura 7

\section{Preguiça}

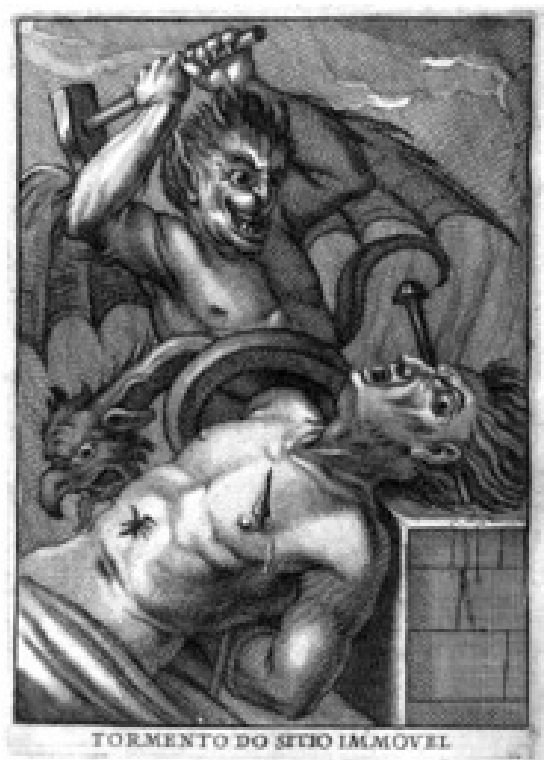

Fonte: PERIER, Alexandre. Desengano dos pecadores, op. cit.

\footnotetext{
${ }^{96}$ A representação do Inferno - rico em suplícios - traduzia o medo do Além e de uma eternidade infeliz. ARIÈS, Philippe. O homem perante a morte, op. cit. p. 118, 123, 133.
} 


\section{As penas do Inferno e o discurso da culpabilidade}

Antes de analisarmos o discurso de Franco acerca das penas que sofriam os pecadores no Inferno - e que visava incutir a culpa nos fiéis —, é interessante notar a representação do inferno presente na obra de Alexandre Perier, Desengano dos pecadores. Perier apresenta o inferno como um "cárcere", como um local de tormento criado para castigar os "delitos mais atrozes dos malfeitores" e os pecadores mais medonhos. ${ }^{97}$ A figura 8 mostra almas desesperadas entre labaredas de fogo, trancadas no subsolo, entre gritos contínuos de $O h$, si daretur hora! (Deus, se nos desse uma hora!), numa referência ao discurso de arrependimento e ao tempo perdido, ao sentimento de culpa e ao desejo - não mais possível, porque já condenado - de reparar os erros cometidos. De certo modo, a imagem sugere que, após a morte, não há perdão, entâo, o sujeito deve arrepender-se e "salvar-se" ainda em vida, pois não há a possibilidade de "ganhar" nem mais uma hora para obter perdão.

Figura 8

\section{Inferno}

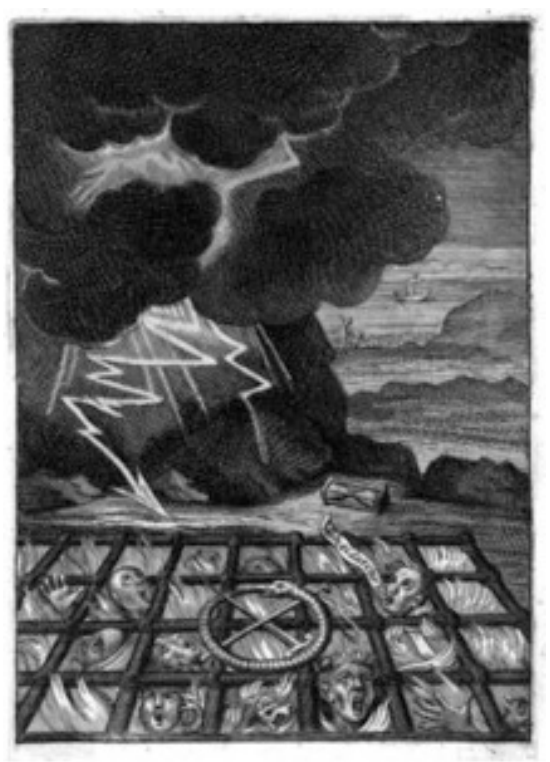

Fonte: PERIER, Alexandre. Desengano dos pecadores, op. cit.

\footnotetext{
${ }^{97}$ PERIER, Alexandre. Desengano dos pecadores, op. cit. p. 45.
} 
Explicitar as penas a que a alma pecadora estaria sujeita foi uma das estratégias discursivas empregadas por João Franco para que seus leitores interiorizassem suas culpas e delas se arrependessem. Esta era uma das intençóes do manual que, de modo estratégico, buscava convencer o leitor sobre a importância da adoção de um padrão cristão de vida, contrapondo o pecado à virtude, a salvação à condenação, o bem ao mal. Assim, para evitar a condenação da alma, recomendava-se que o fiel cristão meditasse e refletisse sobre seus pecados, arrependendo-se em vida, controlando suas paixões e conhecendo os tormentos do demônio e a fúria de Deus. ${ }^{98}$ A meditação e a oração eram práticas recomendadas porque auxiliavam o ser humano a retomar o controle sobre seus impulsos e a agir de forma regrada, como bem destacou Keith Thomas. ${ }^{99}$

Nesse sentido, entende-se a recomendação de que todo e qualquer pecado deveria ser curado com "remédios", sendo um dos principais a prática da oração: "O remédio que os doutores místicos aplicam aos que caem frequentemente em algum pecado é este: escolha o pecado quinze dias nos quais terá em cada dia uma hora de oração ou ao menos meia, se as suas ocupaçóes não lhe derem mais lugar e neste tempo considerará vivamente nas penas do Inferno". ${ }^{100}$

Interessante perceber que para cada pecado era aconselhada a realização de oraçóes com duração de, no mínimo, uma hora diária, por um período de 15 dias $^{101}$ — segundo instruçôes dos "doutores místicos" —, período em que o pecador deveria refletir e evocar em pensamento as inconveniências das "penas do Inferno". Esse processo de cura se daria somente após a interiorização da culpa, o arrependimento e o florescimento do medo da condenação. ${ }^{102}$

O manual aponta também para uma ordem, que previa quatro etapas que deveriam ser

\footnotetext{
${ }^{98}$ Segundo Delumeau, "os teólogos ensinavam que os demônios e feiticeiros se tornavam (...) 'carrascos' do Altíssimo e os agentes de sua justiça”. Deus utilizaria os demônios como executantes de sua justiça. Na mentalidade ocidental, a relação existente entre crime e castigo divino reforçava a ideia do Deus terrível, da divindade que pune os homens culpados. Vingar-se, nesta perspectiva, era algo considerado justo porque atributo da natureza divina. DELUMEAU, Jean. O pecado e o medo, op. cit. p. 201, 335-336.

${ }^{99}$ THOMAS, Keith. O homem e o mundo natural, op. cit. p. 45 apud FLECK, Eliane. Sentir, adoecer e morrer, op. cit.

${ }^{100}$ FRANCO, João. Mestre da vida, op. cit. p. 86-87.

${ }^{101}$ Tanto as instruçôes de condutas chamadas de "remédios espirituais", quanto as próprias "fórmulas" de oraçôes apresentadas são indícios de que o autor previa um retorno do leitor ao texto. O manual, certamente, não se destinava à produção de sentido a partir de uma única leitura, mas também podia ganhar novos significados com a "releitura" e a repetição das fórmulas. CHARTIER, Roger. Do palco à página, op. cit. p. 102. ${ }^{102}$ Numa das obras religiosas analisadas por Cláudia Rodrigues, intitulada Brados do pastor às suas ovelhas (1731), alertava-se para o "arrependimento das próprias culpas ainda em vida”. RODRIGUES, Cláudia. Nas fronteiras do Além, op. cit. p. 68. Ao avaliar as manifestaçôes de sensibilidade religiosa nas reduçôes jesuíticas da Província do Paraguai, no século XVII, Eliane Fleck concluiu que a interiorização do sentimento de culpa pelos indígenas ocorreu simultaneamente à valorização de sensibilidades que exteriorizassem sentimentos de humanidade, piedade, compaixão sensível, bondade e benevolência. FLECK, Eliane. Sentir, adoecer e morrer, op. cit. p. 283. Interiorizar a culpa era reconhecer os pecados para deles, em vida, arrepender-se e deixar a possibilidade de salvação aberta a partir, por exemplo, de práticas piedosas de oraçóes.
} 
observadas ao serem feitas as oraçôes, as quais serão analisadas a partir de agora. Antes de rezar, o fiel deveria "se benzer e invocar a graça do Espírito Santo", ${ }^{103}$ para, então, meditar sobre o primeiro alerta, que enfatizava as características atribuídas ao Inferno, onde o predomínio do fogo levava o corpo e a alma condenada a sofrerem todas as agruras e horrores que as "labaredas de fogo" poderiam provocar:

Como quem está vendo uma cova de largura e profundidade imensa cheia de fogo o mais ativo: a luz dele fúnebre e horrorosa, e dentro da mesma cova os condenados entrando-lhes pelos olhos, ouvidos, boca e nariz, lavaredas de fogo e tornando-as a lançar as mesmas partes; a pele toda incendiada; o sangue fervendo, os ossos e todo o corpo ardendo por dentro e por fora inflamados como carvóes acesos ou como uma estátua de bronze toda roxa com fogo. ${ }^{104}$

Este alerta servia para que o cristáo lembrasse que sua alma poderia arder no fogo como "carvôes acesos". ${ }^{105}$ A segunda etapa previa que, ao rezarem e refletirem sobre seus pecados, os fiéis deveriam perceber que o Inferno era ocupado por muitos infratores da lei de Deus, "muitos mil corpos" condenados que adquiriam deformidades monstruosas inexplicáveis, tais como os demônios que lá existiam. Aos demônios "horrendos" cabia atormentar — de forma contínua, cruel e criativa - as almas, como podemos perceber na passagem que transcrevemos:

Como quem tem diante dos olhos por entre a horrível luz do fogo abrasador não só muitos mil corpos dos condenados que recebem das suas almas impuras uma deformidade tão monstruosa que pessoa alguma jamais poderá explicar, mas também a grande multidão de demônios em figuras horrendas e espantosas, os quais estão em uma ação contínua a atormentarem por modos novos e os mais cruéis aos mesmos condenados. ${ }^{106}$

Como terceiro ponto a ser observado, Franco destaca que, além do fogo e da multidão de condenados e de demônios, ${ }^{107}$ havia de se alertar para os ruídos, os gritos e os lamentos:

\footnotetext{
${ }^{103}$ FRANCO, João. Mestre da vida, op. cit. p.88.

${ }^{104}$ FRANCO, Joáo. Mestre da vida, op. cit. p. 87, grifos nossos.

${ }^{105}$ Note-se que, através da linguagem, João Franco convocava e mobilizava o fiel para, no momento da leitura, criar uma imagem insistente e obsessiva para "invadir" a alma, "ocupando o espírito, trabalhando o sentido, os sentidos, prestes a cruzar as fronteiras do interior e do exterior, transformando-se em visão ou alucinação". CHARTIER, Roger. Do palco à página, op. cit. p. 100. Essa reflexão sobre os pecados cometidos estava presente também nos Exercícios espirituais, redigidos por santo Inácio de Loyola, no século XVI. Especialmente no quinto exercício, Loyola estimulava o conhecimento, a reflexão e o temor das penas do Inferno para que o cristáo pudesse evitar cometer pecados, principalmente, os capitais.

${ }^{106}$ FRANCO, João. Mestre da vida, op. cit. p.87, grifos nossos.

${ }^{107}$ As descriçôes que o dominicano Franco faz dos tormentos demoníacos se aproximam das que o padre jesuíta Antônio Ruiz de Montoya faz na obra Conquista espiritual, de 1639, ao relatar que uma moça dada por morta teria visto "uma tropa de demônios muito feios" e "munidos (...) de garfos". MONTOYA, Antô-
} 
Como quem está ouvindo terriveis alaridos dos demônios, um ruído mais espantoso que o das maiores tempestades e trovóes; os gritos horrorosos que a violência dos tormentos, a raiva, a desesperação fazem arrancar de tantos milhões e milhões de condenados; as lamentáveis queixas contra a sua sorte a mais desgraçada, as acusaçóes e injúrias de uns contra os outros por terem sido a causa dos seus delitos e por terem desprezado os meios de se salvarem; o que tudo produz um novo castigo e uma nova matéria de raiva e desesperação. ${ }^{108}$

O inferno, então, estava representado como o local da raiva, do desespero, dos tormentos, vivenciados por muitas almas que deveriam ter consciência de suas culpas e de que, em vida, não haviam providenciado os "meios de se salvarem". ${ }^{109}$ Uma vez no inferno, não havia para a alma qualquer oportunidade de mudança no seu estado. Por isso, os vivos não deveriam desprezar as oportunidades de realizar o exame de consciência que

implica o exercício da volta do pensamento para dentro de si mesmo objetivando a expiação, a vigilância de si por si mesmo, a culpabilização, a mortificação - tem que doer para purificar! Tudo tem que ser vasculhado: os movimentos do espírito - pensamentos, sentimentos, lembranças — e os movimentos da matéria — as açóes, as tentaçóes, as intenções. ${ }^{110}$

A fim de promover o medo no leitor, Franco lança mão, na quarta e última orientação para as oraçóes, do argumento da cólera divina, tendo Deus como "um Ministro o mais severo e implacável", que condena e estabelece castigos "para sempre, sem nunca acabar". ${ }^{111}$ Diante da eternidade da alma e da possibilidade de infinita condenação, o manual pretendia incutir a ideia de que o fiel deveria trabalhar ainda durante a vida pelo seu aperfeiçoamento moral, controlando seus impulsos, assumindo o compromisso com o "caminho da verdade", pois somente através das boas obras, atitudes, comportamentos e sentimentos dignos depen-

nio Ruiz de. Conquista espiritual. Porto Alegre: Martins Livreiro, 1985 [1639]. p. 154 apud FLECK, Eliane. Sentir, adoecer e morrer, op. cit.

${ }^{108}$ FRANCO, João. Mestre da vida, op. cit. p. 87-88, grifos nossos.

${ }^{109}$ A oposição entre o Céu e o Inferno e entre a salvação e a condenação foi recurso retórico e imagético muito utilizado para a conversão de pagãos e infiéis nos séculos XVI e XVII, como se constata nas gravuras de Pellerin, analisadas por Vovelle. Uma delas, que retrata o tema "Espelho do pecador", apresenta dois coraçôes, o "do cristão que se deixa impregnar pela graça divina" e o "do pecador atacado pelo Maligno". VOVELLE, Michel. As almas do purgatório, ou, O trabalho de luto. Tradução de Aline Meyer e Roberto Cattani. São Paulo: Ed. Unesp, 2010. p. 223-224. Essa observação se torna importante para este artigo, na medida em que reforça a permanência da crença medieval na salvação e do medo da condenação no século XVIII. Jean Delumeau, ao referir-se ao exame de consciência recomendado por alguns pregadores do século XVIII, o definiu como um discurso eclesiástico que visava à "superculpabilização" dos fiéis. DELUMEAU, Jean. O pecado e o medo, op. cit. p. 186-187.

${ }^{110}$ PRADO FILHO, Kleber. Uma genealogia das práticas de confissão no Ocidente, op. cit. p. 144.

${ }^{111}$ FRANCO, João. Mestre da vida, op. cit. p. 88. 
dia a própria salvação. A glorificação da alma passava pela purificação do corpo, que exigia dor física, privação de prazeres e sacrifícios da carne, ou seja, de penitências, de reconciliaçôes com Deus e da eliminação das condutas sociais e morais condenáveis.

Para reforçar seu argumento e conduzir o leitor católico a assumir subjetivamente a culpa por uma possível não salvação da alma, o autor traz o exemplo de uma alma condenada que, dirigindo-se a Deus, pedia a sua destruiçáo, tamanho era o seu sofrimento:

Eu bem sei que vós sois justo vingador e que a vossa justiça não se move aos rogos; porém ao menos fazei que eu sofra um momento ou em tempo limitado todas as penas que eu havia de sofrer por toda a eternidade $e$ depois aniquilai-me. Se ainda assim está satisfeita a vossa vingança fazei que eu experimente os castigos que toda a multidão dos condenados hão de padecer eternamente e depois destrui-me. Se ainda julgais que isto não é bastante em força do vosso poderoso braço para acrescentar sobre mim tormentos táo excessivos em número e em rigor como vos agradar, contanto que passado um dia eu não exista mais. ${ }^{12}$

Atormentada, a alma condenada clamava a Deus por aniquilação e destruição, para que ela não mais existisse e não mais sofresse com os rigores dos castigos. Mas, "vendo que nem isto se lhe concede e que os seus rogos são debalde [inúteis], torna de novo a enraivecer-se, a blasfemar e dizer injúrias contra si próprio, contra os Santos e contra o mesmo Deus". ${ }^{113}$ Ao fim de toda essa aflição, a alma pecadora devia arrepender-se, conscientizando-se da própria culpa:

Ai de mim, que errei o caminho da verdade! De que me serviu entregar-me aos vícios, nutrir-me com negócios injustos, alegrar-me com as vinganças, engolfar-me nos deleites e sensualidades se tudo isto desapareceu como ligeiro fumo? Ai de mim, que por não mortificar as minhas paixóes no pouco tempo que tive de vida venho a padecer os maiores castigos sem consolação, sem remédio e sem medida; porque nunca deixarei de ser atormentado com o mesmo rigor por toda a eternidade. ${ }^{114}$

Os pecados cometidos em "pouco tempo de vida" poderiam ter efeitos "sem remédio" por toda a eternidade, já que a condenação poderia ser eterna. Diante da vida pecaminosa, entregue a paixôes, vícios e deleites, o cristão condenado estaria fadado a nunca deixar "de ser atormentado com o mesmo rigor por toda a eternidade". ${ }^{115}$ Esse seria o maior suplício e sofrimento de quem morreu em pecado, sem o necessário conhecimento de si, sem a eliminaçáo dos maus pensamentos, e, portanto, sem o direito de purgar seus pecados.

\footnotetext{
${ }^{112}$ Ibid., p. 88-89, grifos nossos.

113 Ibid., p. 89.

${ }^{114}$ Ibid., p. 89, grifos nossos.

115 Ibid., p. 89.
} 
O manual ainda reforça - como "verdade infalível" — que as penas do Inferno estavam muito além da imaginação humana, uma vez que "a força de um Deus Todo-Poderoso justamente irritado as destinou para vingar com todo o rigor as suas ofensas". ${ }^{116} \mathrm{O}$ discurso mobilizador de João Franco estabelece a necessidade de o fiel renunciar ao corpo e ao desejo — ligado aos apetites da carne, às fantasias sexuais e às vaidades corporais — como um meio de transformação íntima fundamental para a conquista da vida eterna.

Aos leitores, orientados por estas instruçóes, caberiam condutas compatíveis com os desígnios divinos defendidos pela Igreja. Para reforçar seus argumentos, Franco destacava a irreversibilidade da sentença final, orientando os leitores a refletirem sobre suas culpas e sobre a possível condenação de sua alma: "Demônios, que lugar tendes aparelhado para uma criatura táo perversa como eu? Que tormentos para uma pessoa que estando obrigada pelos votos do Batismo e pelos auxílios recebidos da mão de Deus a ser santa, desprezou ao mesmo Deus e meteu debaixo dos pés a sua Lei??. ${ }^{117}$

O manual apresenta certa recorrência da estratégia narrativa do contraponto entre Deus e Demônio e entre Céu e Inferno, com o objetivo de destacar os sofrimentos experimentados pela alma condenada. ${ }^{118} \mathrm{O}$ leitor deveria ser levado a viver santamente, mediante a contínua reflexão sobre os malefícios que as almas condenadas sofreriam eternamente nas trevas, como se pode constatar nesta orientação:

e hei de ser eu tão louco e tão bárbaro que me atreva a pecar manifestando, ainda que não com palavras ao menos com as obras, que quero ser escravo do demônio, marcado com o seu selo e riscado do livro da vida! Quero, como eles, padecer, gritar, enraivecer-me e blasfemar dos Bemaventurados, dos Santos, dos Anjos, de Maria Santíssima e de Deus! Quero dar o coração, corpo e alma aos demônios para me atormentarem eternamente no Inferno e isto só por não deixar os meus pecados e maus costumes! Eis aqui o que faço todas as vezes que peco. Que cegueira! Que temeridade! ${ }^{119}$

\footnotetext{
${ }^{116}$ Ibid., p. 89. Vale lembrar que, em meio às pestes que grassavam na França dos séculos XVII e XVIII, as pessoas se perguntavam: "de quem é a culpa?". A resposta apontava para a irritaçáo de Deus, que decidira vingar-se contra "os pecados de uma população inteira”. DELUMEAU, Jean. O pecado e o medo, op. cit. p. 201. ${ }_{117}$ FRANCO, João. Mestre da vida, op. cit. p. 89-90. Michel Foucault, baseando-se nas ideias do cristão cartaginês Tertuliano (séculos II e III), expostas em sua obra $A$ penitência, afirma que o cristáo tinha dois caminhos a seguir: ou mostrar-se como pecador, "como alguém que, escolhendo o caminho do pecado, preferiu a imundície à pureza, a terra e a poeira em vez do céu, a pobreza espiritual aos tesouros do céu”, ou, então, "expressar sua vontade de libertar-se desse mundo, de livrar-se de seu próprio corpo, de destruir sua própria carne e ter acesso a uma nova vida espiritual”. FOUCAULT, Michel. Do governo dos vivos, op. cit. p. 173.

118 Também em relação a este recurso retórico empregado por Franco, constata-se grande semelhança com as adotadas pelos missionários jesuítas na conversão dos nativos americanos. Nas Cartas Ânuas enviadas ao Padre Geral da Companhia de Jesus, os padres relatam que "as aterradoras descriçôes dos demônios e do inferno" contrastavam com "as dos santos, dos anjos e do céu", que visavam a "transmitir a ideia de tranquilidade, beleza e harmonia, em situaçóes que envolviam a absolvição dos pecados, o alcance [de alguma] cura ou a garantia da boa morte". FLECK, Eliane. O domínio das almas, op. cit. p. 80.

${ }^{119}$ FRANCO, João. Mestre da vida, op. cit. p. 90, grifos nossos.
} 
O pecado e a persistência nos atos falhos eram tidos como um desejo intenso do fiel em firmar pacto com o Demônio e encaminhar sua alma ao Inferno, de modo que por sua condição de pecador, "depravado" e "entregue a hábitos criminosos" deveria realizar oraçôes a Deus, reconhecendo e confessando seus erros, sua cegueira e suas paixóes. Ao passo que Deus, "justamente irritado", poderia ser pacificado através do sacrifício e da humildade do pecador que prometeria não mais ofendê-lo, pediria perdão, imploraria piedade e "mil vezes misericórdia”. ${ }^{120}$

A clareza em relação ao mal causado pelos pecados, às experiências do inferno e à compreensão da fúria de Deus contribuía para o desenvolvimento da experiência subjetiva de exercitar o caminho da salvação através da aceitação da culpa, da confissáo, da puniçáo e da penitência. Os 15 dias de oraçôes sugeridos, inicialmente, eram para que o cristão estivesse certo de que, desse modo, "há de conseguir o favor do Céu, como a experiência tem mostrado". ${ }^{121}$

Eliminar os pecados da vida significava não apenas uma mudança de atitudes e de conduta social, mas, também, de pensamento. Viver de modo devoto e caridoso, em obras e em sentimentos, seguindo os princípios e as determinaçôes do catolicismo romano foram algumas das recomendaçôes de Franco, que enfatizou - como todos de sua época - os infortúnios do Inferno e o reconhecimento explícito das culpas.

\section{Últimas consideraçóes}

Buscar as "ocasiôes da culpa" e não viver em pecado mortal são as principais recomendações que João Franco ${ }^{122}$ faz no manual Mestre da vida. Para o padre dominicano, o exame constante e diário da consciência - para verificar em que estado "se acham as paixões dos teus apetites e a resistência que lhes fazes para as venceres" ${ }^{123}$ — deveria ser uma prática cotidiana do bom cristâo, visando à purificaçáo da alma.

O incentivo à culpabilização ou, nas palavras de Delumeau, à superculpabilização, que "maximiza as dimensôes do pecado em relação ao perdão", 124 está bastante evidente no texto do manual, na medida em que propôe que seu leitor sinta um "verdadeiro pesar" das suas culpas, "pelo temor das penas eternas". ${ }^{125} \mathrm{O}$ pecador era "réu de muitas culpas diante de

\footnotetext{
${ }^{120}$ Ibid., p. 90 .

${ }^{121}$ Ibid., p. 92.

${ }^{122}$ Ibid., p. 13.

${ }^{123}$ Ibid, p. 15.

${ }^{124}$ DELUMEAU, Jean. O pecado e o medo, op. cit. p. 15.

${ }^{125}$ FRANCO, João. Mestre da vida, op. cit. p. 18.
} 
Deus", ${ }^{126}$ pois, além dos pecados cometidos, suas culpas podiam servir de exemplo para os outros, ${ }^{127}$ por isso deveria saber dos valores a adotar para si e para os outros ainda em vida.

O homem que, intencionalmente, cometesse os sete pecados capitais era considerado "depravado" e "abominável", ${ }^{128}$ porém todos os seres humanos, segundo Franco, estavam sujeitos a incorrer em pecado. Ao bom cristáo cabia exprimir seus desejos de arrependimento, diante da gravidade dos pecados cometidos, recorrendo à seguinte oraçáo: "Perdoai-me todos os meus pecados, abri as vossas chagas e espalhai o vosso sangue sobre a minha alma culpável”. ${ }^{129}$

Ao abordar os malefícios dos pecados capitais e oferecer "remédios" para eliminá-los ou "curá-los", o manual cumpria uma missão clara e precisa: conduzir os sujeitos pecadores a conhecerem-se, a estabelecerem uma relação consigo, a meditarem sobre suas atitudes e pensamentos; e, assim, sujeitos dóceis (sem ira), obedientes à Igreja (sem soberba e avareza), com atitudes moralmente aceitas (sem luxúria), com hábitos saudáveis (sem gula e sem preguiça), enfim, sujeitos capazes de contribuir com e para a Igreja Católica. A vigília estaria sob responsabilidade da própria consciência do indivíduo, do seu discernimento entre o bem e o mal e da sua certeza entre as diferenças do Céu e do Inferno, que os padres, como porta-vozes da Igreja Católica, se encarregaram de divulgar através de sermóes e de obras como o manual de devoção analisado neste artigo.

As imagens da obra de Alexandre Perier impressionam, justamente, pela representação que trazem da condenação da alma, mediante o ataque por demônios e por animais, evidenciando as características mais condenáveis de cada pecado capital: ao soberbo e ao preguiçoso, está reservada a imobilidade; ao irado, a perfuração do coração; ao guloso, a ingestão de insetos; ao luxurioso, as mãos acorrentadas; ao invejoso, a venda nos olhos; ao avarento, o banho de moedas.

Esta orientação moral cristã se disseminou pela Europa e, também, pela América, entre o século XVIII e o XIX, como comprova o sucesso editorial do manual Mestre da vida. É correto afirmar que as inúmeras possibilidades de recepção e apropriação destes manuais estiveram condicionadas ao público leitor (ou ouvinte) — ou dos viajantes do espaço e do tempo, como nas palavras de Certeau -, que sobre eles lançaram diferentes motivaçóes e sentidos. No entanto, pode-se também afirmar que o texto do manual foi, durante muito tempo, resposta às perguntas de seu tempo, podendo ser entendido como o espaço da recepçáo esperada ou, em outras palavras, como resposta a questionamentos como aquele que Umberto Eco propóe na epígrafe deste artigo: E que contaremos então aos pecadores se não podemos ameaçá-los com um inferno imediato, logo após a morte?!

\footnotetext{
${ }^{126}$ Ibid., p. 19.

${ }^{127}$ Ibid., p. 48.

${ }^{128}$ Ibid., p. 27.

${ }^{129}$ Ibid., p. 28-34.
} 
É, portanto, acertado supor que tanto as interpretaçóes, quanto os usos da ideia de pecados capitais possam ter mudado. No século XVIII, eles eram fruto da atividade de reforço da teologia moral cristã pós-tridentina para a conversão dos povos, a contenção do avanço protestante e a defesa dos argumentos religiosos diante do avanço da filosofia racional iluminista; no século XIX, período em que os manuais ainda eram lidos, embora menos editados, as referências aos pecados capitais continuaram a fazer parte do universo discursivo católico e à disposição de quem deles quisesse fazer uso, especialmente durante o Papado de Pio IX (1846-1878) que, dado o conservadorismo, incentivou a retomada de tradicionais valores religiosos para os cristãos. ${ }^{130}$

O fato é que a Igreja exerceu, por longo período, o domínio das consciências e, nos séculos XVIII e XIX, as ideias do pecado e da culpa ainda dominavam fortemente as sensibilidades religiosas dos cristãos. De tal modo que Joáo Franco foi levado a instruir seus leitores a dizer em oração: "Eu tenho pecado; e se disser outra coisa sou um mentiroso". Séculos depois, de modo semelhante, o historiador Delumeau declarou: "Eu creio que o pecado existe. Eu constato sua presença em mim". ${ }^{131}$ Essa afirmação parece confirmar o quanto a Igreja foi bem-sucedida em seu esforço de tornar o fiel - consciente de sua culpa e da condição de pecador - vigilante de si mesmo, a fim de garantir uma alma livre de todo o pecado, livre de todo pecado capital e, consequentemente, das penas do Inferno.

Artigo recebido em 18 de fevereiro de 2013 e aceito em 20 de maio de 2013.

* Doutora em história pela Pontifícia Universidade Católica do Rio Grande do Sul (PUC-RS), professora da Universidade do Vale do Rio dos Sinos (Unisinos), bolsista de produtividade científica do CNPq, nível 2. São Leopoldo, RS, Brasil. E-mail: ecdfleck@terra.com.br.

${ }^{* *}$ Doutor em história pela Universidade do Rio dos Sinos (Unisinos). São Leopoldo, RS, Brasil. E-mail: maurodillmann@hotmail.com.

\footnotetext{
${ }^{130}$ No século XIX, houve uma defensiva das doutrinas oficiais da Igreja nos diversos ramos do conhecimento e do apostolado, bem como um remanejo das antigas ordens religiosas e na formaçấo de novas ordens e congregaçóes devotadas ao trabalho missionário. Pode-se dizer que a postura doutrinária da Santa Sé se consolidou com as encíclicas Quanta cura e Syllabus (1864) que condenavam os "erros modernos", como o racionalismo, o socialismo, o comunismo, a maçonaria, a separação entre Igreja e Estado, o liberalismo etc. Essa reforma na Igreja ficou conhecida também como ultramontanismo, na medida em que o mundo cristão católico seguiu as determinaçóes papais de repúdio à civilização moderna. Desde entâo, os órgãos dirigentes da Igreja promoveram um culto à figura do papa, chegando a proclamar o dogma da infalibilidade papal no primeiro Concílio Vaticano (1870). MICELI, Sérgio. A elite eclesiástica brasileira, 1890-1930. São Paulo: Companhia das Letras, 2009. p. 18.

${ }^{131}$ DELUMEAU, Jean. O pecado e o medo, op. cit. p. 15.
} 